Portland State University

PDXScholar

\title{
A study to determine the relationship between interest as measured by a Student interest inventory and recreational nonfiction books checked out of the library media center by intermediate grade students at Sunnyside Elementary School, North Clackamas School District Number 12, Clackamas, Oregon
}

Larry Charles Leedy

Portland State University

Follow this and additional works at: https://pdxscholar.library.pdx.edu/open_access_etds

Part of the Elementary Education Commons, and the Reading and Language Commons Let us know how access to this document benefits you.

Recommended Citation

Leedy, Larry Charles, "A study to determine the relationship between interest as measured by a Student interest inventory and recreational nonfiction books checked out of the library media center by intermediate grade students at Sunnyside Elementary School, North Clackamas School District Number 12, Clackamas, Oregon" (1982). Dissertations and Theses. Paper 3349.

https://doi.org/10.15760/etd.5008

This Thesis is brought to you for free and open access. It has been accepted for inclusion in Dissertations and Theses by an authorized administrator of PDXScholar. Please contact us if we can make this document more accessible: pdxscholar@pdx.edu. 
AN ABSTRACT OF THE THESIS OF Larry Charles Leedy for the Master of Science in Education with an emphasis in Iibrary media/Iibrarianship presented July 18, 1983.

Title: A Study to Determine the Relationship Between Interest as Measured by a Student Interest Inventory and Recreational Nonfiction Books Checked Out of the Library Media Center by Intermediate Grade Students at Sunnyside Elementary School, North Clackamas School District Number 12, Clackamas, Oregon.

APPROVED BY MEMBERS OF THE THESIS COMMITTEE:
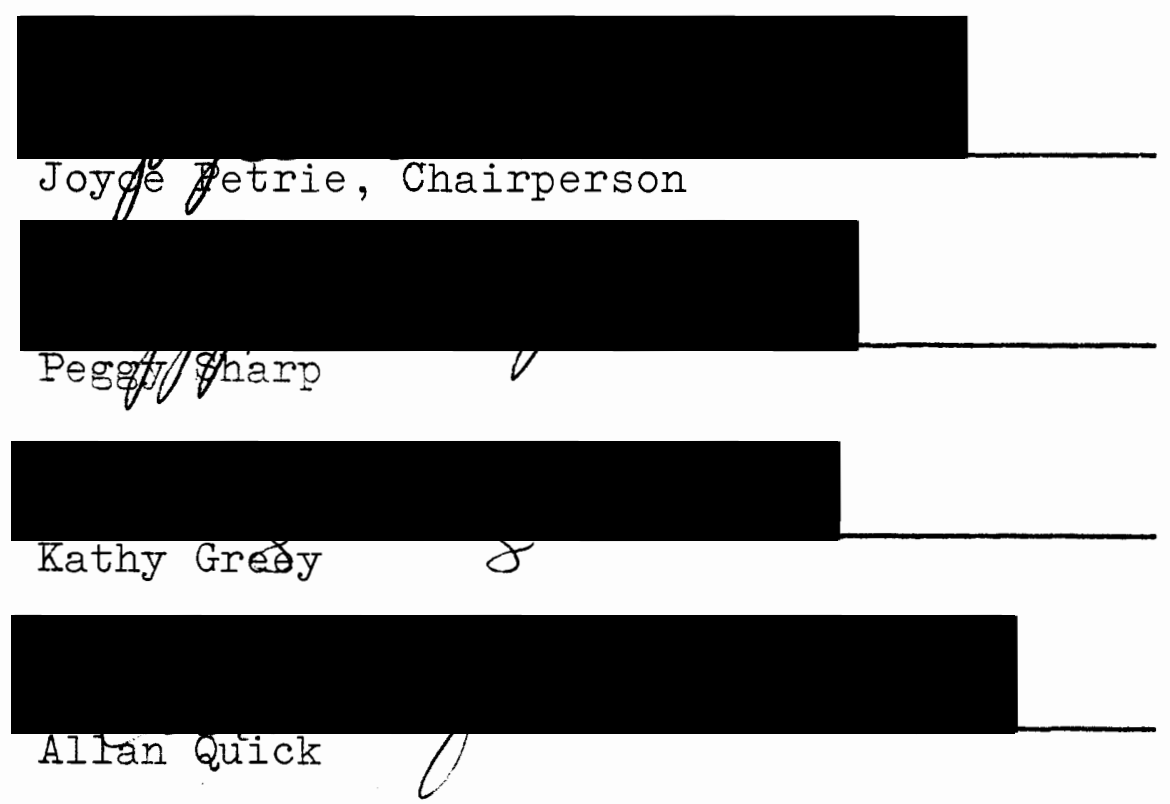

The purpose of this study was to determine if a correlation existed between the selection of recreational nonfiction books from a school library media center by elementary 
school students in grades four through six and the measured interest, as generated by the Student Interest Inventory, of the students. Data for this study was collected during the period September, 1982 and April, 1983 at Sunnyside Elementary School, North Clackamas School District Number 12, Clackamas, Oregon. The raw data for the measured interest and recreational nonfiction books checked out were arranged by Dewey Decimal Classification tens. By using the Pearson product-moment correlation formula a significant coefficient was found and it was concluded that a correlation did exist between measured interest and nonfiction recreational books actually checked out of the library media center. 
A STUDY TO DETERMINE THE RELATIONSHIP BETWEEN INTEREST AS MEASURED BY A STUDENT INTEREST INVENTORY AND RECREATIONAL NONFICTION BOOKS CHECKED OUT OF THE LIBRARY MEDIA CENTER BY INTERMED IATE GRADE STUDENTS AT SUNNYSIDE ELEMENTARY SCHOOL, NORTH CLACKAMAS SCHOOL DISTRICT NUMBER 12, CLACKAMAS，OREGON

$$
\text { by }
$$

LARRY CHARLES LEEDY

A thesis submitted in partial fulfillment of the requirements for the degree of

\author{
MASTER OF SCIENCE \\ in \\ EDUCATION
}

Portland State University 
TO THE OFFICE OF GRADUATE STUDIES AND RESEARCH:

The members of the Committee approve the thesis of Larry Charles Leedy presented July 18, 1983.
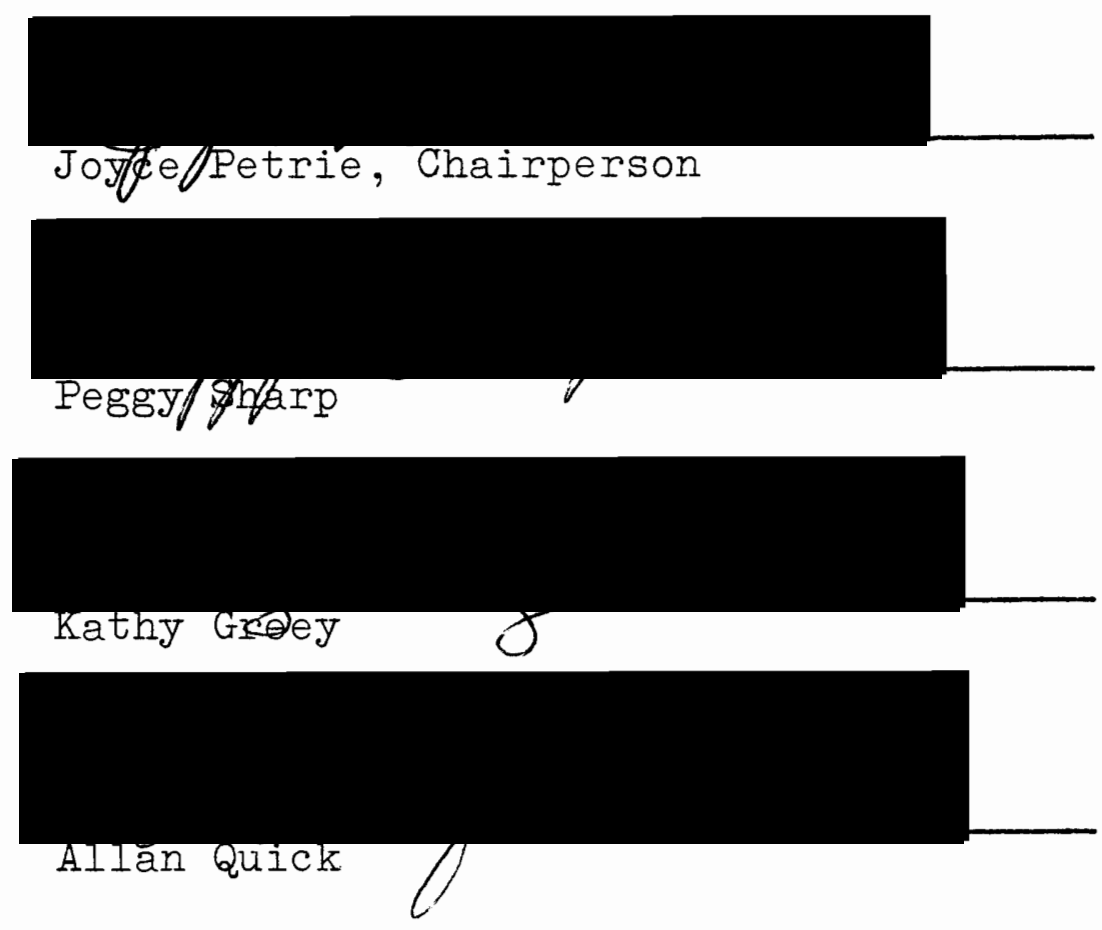

AFPROVED :

Carol Burden, Head, Department of Special Programs

Stanley . Rauch, Dean of Graduate Studies and Research 


\section{ACKNOWLEDGMENTS}

A sincere acknowledgment of appreciation is hereby given to Dr. Robert $S$. Orr, my principal and friend, for his assistance, encouragement, and released time to complete this study.

A special acknowledgment is due Dr. Sheridan D. Jones, Director of Teacher Development, North Clackamas School District Number 12, for his assistance through the statistical portion of this study and for his continued support and encouragement.

Much valuable assistance in the refinement of the final copy was provided by Dr. Charles W. Bursch, retired, Gary Peterson, teacher, Sunnyside Elementary School, and my aide, Mary Swanson.

Appreciation is also extended to the members of the thesis committee, Dr. Joyce Petrie, Peggy Sharp, Kathy Greey, and Allan Quick.

Finally, to my wife Annlie and our daughters, Larissa, Iisa, and Tara, I wish to express my deepest appreciation for their encouragement and support throughout this entire stuãy. 
TABLE OF CONTENTS

PAGE

ACKNOWLEDGMENTS . . . . . . . . ........

LIST OF TABLES . . . . . . . . . . . . . . V Vi

LIST OF FIGURES . . . . . . . . . . . . . . ViIi

CHAPTER

I INTRODUCTION . . . . . . . . . . . . I 1

Statement of the Problem ...... 9

Hypothesis ........... 18

Importance of the Study . . . . . 18

Definition of Terms ....... . 24

Organization of the Study . . . . 26

II A REVIEW OF THE IITERATURE . . . . . . 28

Introduction ........ . 28

Reported Methods for Studying Reading

Interests......... 29

Findings of Studies Reported in the

Literature ........... 33

II METHOD OF STUDY . . . . . . . . . 36

Introduction . . . . . . . 36

Development of the Student Interest

Inventory . . . . . . . . . 37

Phase I--Developmental stage

Phase II--Iibrary Media Teacher

Validation Process 
Phase III--Student Validation Process

Phase IV--Third and Final Draft

Dewey Decimal Classification Tens

Summary •. • • • • • • • • • •

Method of Correlation . . . . . . 42

The Sample . . . . . . . . . 43

Method of Analyzing the Data . . . . 44

IV FINDINGS OF THE STUDY . . . . . . . . 48

V SUMIMARY, CONCIUSIONS, AND RECOMMENDATIONS • 54

Summary . . . . . . . . 54

Conclusions.......... 55

Recommendations . . . . . . . 55

REFERENCES

APPENDIX

A Cover Letter and Student Interest Inventory, Drafts 1, 2, and 3....... 64

B Dewey Decimal Tens Summary Worksheet . • 75

C Dewey Decimal Classification Numbers and Subject Headings . . . . . . . .

D Summary of Classification Numbers and Subject Headings, and Classification Numbers and Subject Heading Clusters Summary . . . . . . . . . . .

E Ratio of Books Checked Out to Measured Interest ............ 100

F Student Interest Inventory Specific and General Desires and Books Checked Out. 103 


\section{IIST OF TABLES}

TABLE

PAGE

I Totals of Student Interest Inventory Specific and General Areas and Books Checked Out of the Library Media Center . . . . .

II Total Class Ratios for Specific and General Interest Areas and Books Checked Out . . 50 II Totals of Books Checked Out and Specific and General Interest . . . . . . . 52

IV Ranges of Correlation Coefficients . . . . 53

$\checkmark$ Summary of Dewey Decimal Classification Numbers and Subject Headings . . . . . . . 88

VI Dewey Decimal Classification Numbers and

Subject Heading Clusters Summary . . . . 97 VII Ratio of Books Checked Out of the Iibrary Media Center to Measured Interest Arranged by Dewey Decimal Classification Tens $\operatorname{Span}$. . . . . . . . . . 101

VII Student Interest Inventory Specific Desires and Books Checked Out of the Iibrary by Dewey Decimal Classification Tens Spans . . . . . . . . . . . 104 
vii

TABLE

PAGE

IX Student Interest Inventory General Desires

and Books Checked Out of the Iibrary

by Dewey Decimal Classification Tens

Spans . • • • . • . . . . . . . . . 107 


\section{IIST OF FIGURES}

FIGURE

PAGE

1. Comparison of Specific Interests and Books

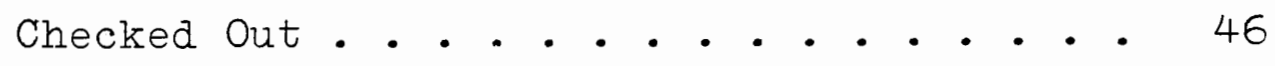

2. Comparison of General Interests and Books

Checked Out . . . . . . . . . 46

3. Formula for the Standard Error of the r. . . 47

4. Computations for the Standard Error of the $r$. 47 


\section{CHAPTER I}

\section{INTRODUCTION}

The names of Judy Blume, Beverly Cleary, C. S. Lewis, Walt Morey, and J. R. R. Tolkien are current names with whom most children are familiar. The names of Isaac Asimov, Tom McGowen, Millicent E. Selsam, and Herbert S. Zim are not as familiar. The first group of writers are authors of fiction, the second group are authors of nonfiction. The unfamiliarity of these nonfiction authors cannot be explained by the premise that there are many more readers of fiction than nonfiction. The writers of nonfiction for children generally are not universally thought of as writers in the same connotative sense as authors of children's novels. Nonfiction, or informational books, are far more often reviewed for their content, rather than their total literary value. They are not considered by most to be creative writers. More often reviewers of nonfiction books comment on the factual errors, rather than criticize the style with which an author has presented his facts. This reviewing trend is slowly changing and today there are many good sources of reviews that critique both content and style of nonfiction literature. Consequently, nonfiction authors are writing quality books and there are 
many books available to help children of all ages satisfy their curiosity about the world of the past, the world of the present, and the world of the future (Fisher 1972, p. 10).

The world that we live in today is a world of the mass media: books, newspapers, magazines, comic books, radio, movies, television, and computers. It is a society centered around the media. Although our society is centered around this mass media, there still remains a need to be able to read and communicate through the written word. This is especially true for our schools, which tend to be print oriented. In addition, as long as people communicate with one another, take part in educational endeavors together, and engage in recreational activities, reading will continue to be a chief means of communication, education, and recreation. Reading is a medium for learning. Without a developed ability and desire to read, a student is likely to fail in a society that is dominated by a mass media that still tends to be print oriented. One needs to be able to function within this media, necessitating the ability to communicate through the written word. Reading is a learned process which is highly correlated with the other communicative skills.

The instruction and maintenance of reading skills is no longer considered a separate entity. The ultimate reason for teaching reading is to introduce the world of 
books to children and direct them toward a lifelong pursuit of enjoyment for reading. Thus, the well written book becomes a model of organization in which children gain an understanding of a universe that stretches immeasurably beyond their own limited experiences. To promote this lifelong pursuit of enjoyment for reading, reading interests of children become primary concerns to educators. Hurley (1970) expresses the importance of both parents and teachers in the involvement of the reading experiences of children:

Although children are individuals and differ as to sex, age, intelligence, environment, reading ability, and instinctive elements, there is an amazing consistency in patterns of reading interests, beginning in preschool. The early influence of parents reading to the child, of helping a child build a library, and of the child's own bookcase, have important results in school. Likewise, reading experiences in the elementary grades lead to a pattern of liking or disliking books which become fixed in the fifth grade (p. 96).

A large percentage of each school day in the elementary schools is spent directly or indirectly in the teaching of reading. The students are exposed to print materials in almost every discipline in which they are involved. Students appear to find some of this material interesting, while a similar amount is considered uninteresting. Thus, the teacher has a major role to provide interesting and stimulating print materials as part of their lessons to promote the student towards a learning experience. 
At most schools children are surrounded with print materials. Many classrooms have individual classroom libraries and most schools have some type of central library providing selections of various types of books and materials that should appeal to the student. Many schools have volumes upon volumes of library books awaiting the selection by some eager child who is in the pursuit of recreational reading. However, within these same walls we have students who are not concerned with reading, who are not influenced with the amount of library and classroom books available, and who usually leave the library without finding a book that was of interest.

Many students are plagued with reading difficulties and a reluctance to read which centers on one prime factor, "interest." This may lead to a lack of interest in reading and subsequently a lack of interest in school itself. Kopel (1963) comments on what makes an activity interesting:

What makes an activity interesting is not that it is "easy" but rather, that it is challenging--which means that it presents obstacles that can be overcome--necessarily through effort. The responsibility of the teacher, then, is to nurture an interest in reading by his own enthusiasm for reading and by skillfully guiding the pupils in a stimulating reading program . . . Interest in reading develops with the skills and abilities of learning to read and is generally proportionate to the meaning a child receives from reading. . . While competency in reading affects interest in reading, particular interests, or special competencies in other areas of learning, are often important determinants of reading interests ( $p$. 501). 
Neuman (1982) indicates that there is a strong need to promote reading as a leisure time activity. She states:

Not only does recreational reading encourage the development of interest, it provides students with opportunities to acquire self-insight, knowledge, and social awareness that are independent of their immediate environment ( $p$. 299).

There is a need for recreational reading, but studies have indicated that the amount of time devoted to leisure reading has remained minimal in comparison to other recreational activities (Witty 1967, p. 534; Greaney 1980, p. 347 ).

In the pursuit of providing children with good reading experiences, teachers and library media teachers should have the goal of providing children with books and materials that are of interest to them. It is the hope of educators to instill children with the realization that reading is fun. As noted in the proceedings of the National Society for the Study of Education (1964):

The reading interests with which children come to school are our opportunity, but the reading interests with which they leave school are our responsibility (p. 248).

Children are our future. When confronted with statistics of reading habits of people of the United States, educators must look with concern at whether or not the goals of teaching children to read and enjoy reading as a recreational activity have been achieved. Levy (1979) looks with alarm at the National Opinion Research Center statistics: 
It is staggering to read the results of surveys by the National Opinion Research Center which shows that citizens of the United States read fewer books than the citizens of Great Britain, France, Germany, Holland, Switzerland and the Scandinavian countries; that approximately ten percent of our population reads eighty percent of the books; that about half the adult population of the U.S. has never read a book all the way through; and that fewer than one-out-of-five adults could name a book they would like to read (p. 22).

These statements are not new. In 1925 the following appeared in the Twenty-Fourth Yearbook of the National Society for the Study of Education:

Thousands who learned to read in school read very little, if at all, as adults. Furthermore, a surprisingly large number of people state frankly that they are not interested in reading or that they do not know where to secure materials which they might care to read (p. ll).

Again in 1957 Florence Cleary points out what the research of the day summarized:

While it is true that surveys of adult reading habits gives contradictory reactions regarding the amount and quality of reading done by the average American, a number of carefully documented studies provide evidence to show that nearly twothirds of the adult population may be considered non-readers of books; that 75 per cent of the books published are read by five per cent of the people; that public library card holders comprise only 25 per cent of the adult population, and only ten per cent use the library as often as once a month; that pulp magazines and newspapers are the major source of reading materials; and that the general effect of the reading done by many adults is aptly described by Edgar Dale when he states that while reading, like watching television, may help to mature people, it may also arrest them at an infantile level of development (p. 18).

These statistics and statements should be of great alarm to those in the field of education. The many and varied 
interest surveys that are being conducted throughout the United States and many parts of the world today point out the need for finding out what student interests are and then providing for those interests. However, many problems are encountered in this search for the reading interests of children.

One of the main problems encountered in trying to determine children's reading interests is the impossibility of comparing interest studies due to the diverse methods of investigation involved. The studies seem to have no common criteria, either of content or design. Thus, it is evident that before the results of research in children's literature can be compared to form conclusions of substantial validity and importance, standard procedures of investigation must be prescribed (Tibbetts 1975, p. 504).

Those concerned with providing children with excellent literature are confronted with yet another problem-one of definition. The definitions of "fiction" and "nonfiction" according to the World Book Dictionary, c1973 are :

FICTION :

novels, short stories, and other prose writings that tell about imaginary people and happenings. . . made-up story.

NONFICTION: prose literature that is not a novel, short story, or other form of writing based on imaginary people and events. 
Dawkins (1977) points out a concern over the definitions of fiction and nonfiction:

The common definitions clearly cut the word or prose into two parts, writings about imaginary or made-up events and writings about true or factual events. But they don't work very well . . we are saying that fiction is about made-up things and nonfiction is about real things ( $\mathrm{p} .127$ ).

These factual or informational books have long been labeled nonfiction, thus causing many adults and children to consider these books as not as desirable as fictional literature. This attitude is compounded by children's literature courses which stress fiction reading, but do not emphasize nonfiction literature. Margery Fisher (1972) states:

The distinction between fiction and non-fiction is no clearer if we use the terms "information books" and "stories." A great many factbooks make use of incident fiction, and who could argue that fiction had no element of fact? The distinction between fiction and non-fiction is blurred and constantly shifting, but we still use it and need it. We have to accept the convenience that lies behind this naive generalization for very young readers: There are shelves of books in the library. The story books are called fiction. Other books, not stories, are called non-fiction. These are books about history, nature and hobbies.

Like so many general terms, "non-fiction" represents a compromise with some sense in it ( $p .13)$.

Jo Carr (1982) also stresses this positive attitude toward nonfiction, a term that can be very controversial:

Fact is different from fiction; not necessarily better, but different. Children should have the privilege of knowing both ( $p$. 9l). 
One characteristic that children seem to have in common is curiosity. To satisfy this curiosity, whether the book is chosen to answer questions that the child might ask, to answer questions asked of the child by a teacher, or to fulfill a desire to broaden knowledge, children search out and read nonfiction books (Sutherland, Monson, and Arbuthnot 1981, p. 442).

Stauffer (1958) summarizes the reading experience in the following comment:

Love for reading is not taught, it is created; not required, but inspired; not demanded, but exemplified; not exacted, but quickened; not solicited, but activated. To stimulate personal and social growth through reading, the teacher must be the most experienced person about books for children (p. 29).

\section{STATEMENT OF THE PROBLEM}

Children's reading interests have been a concern of researchers since the turn of the century. It has been determined that it is important for teachers and library media teachers to know the interests of their students to aid in the development of reading and the pursuit of developing lifetime readers. Helen Hus (1972) points to this need in her statement:

If teachers are to make lifetime readers of their students, one of their cues to successful teaching is to note the pupils' reactions to books in order to capitalize on their interests revealed, the books that are enjoyed, and the influences that reading has on subsequent behaviors ( $p .25)$. 
Determining this interest presents a problem. Currently there is a controversy over how to test for student interest. Many researchers feel that due to the diverse methods of investigations currently employed there is a need for a reliable, practical instrument to determine the interests of the students. The researchers indicate that to date there is no such instrument available.

Research into student interests also draws attention to general interest in subject areas and does not attempt to determine specific areas such as fiction or nonfiction. In this search for student interests, nonfiction literature seems to be neglected. It was to this end that this study to determine if there is a correlation between student interests and nonfiction recreational reading was conducted.

Children's reading interests have been a constant concern of educators for many years. This is evident from the extensive emphasis that has been placed on reading interests since the beginning of the 20th century and especially during the past four decades. Purves and Beach, writing in 1972, stated that there had been some 360 studies on reading interests to that date. Most reading interest studies at the elementary school level have focused on grades four through six. The reading interests of the students concerning books read and liked have been studied using such techniques as questionnaires (Iancaster 
1928; Witty, Coomer, and McBean 1946; Rudman 1955; Witty and others 1959; Ashley 1970; Chiu 1973; Beta Upsilon Chapter 1974; and Shores 1974); interviews (Stanchfield 1962; and Geeslin and Wilson 1972); relating freely discussed topics to interest (Byers 1964); free choice library selection (Smith 1962); responses to oral presentations (Cappa 1958); combining questionnaires and picture rating scales (Stevens 1981); use of nonverbal, nonreading picture evaluations (Ford and Koplyay 1968; McNinch 1970-71; and Brown and Krockover 1974); and fictitious, annotated titles (see definition of terms) (Thorndike and Henry 1940; and Feeley 1974, 1982). These studies have sought to answer questions about preferences and habits of children toward reading; likes and dislikes; sex differences; effects of age and grade level upon reading; geographical locations in conjunction with reading interests of students; achievement and IQ; and other influences affecting the reading interests of students.

Since attitudes develop early, the elementary school years are critical. Witty and Kopel in Ashley (1970) made the following statement in 1939:

At twelve or thirteen years the amount and variety of reading activity of typical boys and girls approaches its peak. Children now show some interest in almost every field of literature. . . (p. 1095).

Ashley (1970) in his study of 900 elementary students in grades four through seven found that the peak and amount 
of reading comes in the 10-11 year range. He also found that the interests in almost every field of literature falls away quite sharply in the latter half of the sixth grade. In his summary Ashley states:

The best chance of encouraging good reading habits lies in--and before--grade 4. There is still some hope in grade 5. There is very little chance at all after grade 5 , since by this stage reading tastes have become well-nigh crystallized. After grade 5 the probable major task is one of salvage . . (p. 1096).

Neuman (1980) in a study of 313 students ranging from grades three through nine in 12 different schools concluded:

Students interest in using reading for learning seemed to "peak" at grade 6 , then drop consistently thereafter. What this might suggest is that students tended to regard reading as the mastery of skills rather than as an avenue for further exploration of ideas and information. It might also indicate a need for greater emphasis in developing reading in the content area $(p .336)$.

A current analysis of television viewing and leisure reading by Neuman reflected that students who watch television three or more hours a day and read less than two books a month chose books significantly lower in quality than others in the sample group (Neuman 1982, p. 303). Neuman points to the results as extremely important to educators, especially in light of recent research conducted by Himmelweit and Swift (1976). In view of this report, she states:

A twenty year longitudinal study of the relationship between television and other media including 
reading, radio, and cinema going, indicate that the patterns of media preferences and tastes established by youngsters at ages 13 and 14 were highly predictive of their adult use of media. Thus, for example, interest in high quality reading materials as an adolescent correlated highly with preferences for similar content in adult life. Tastes for strong stimulation (violence and adventure), as well, showed similar content over time ( $\mathrm{p}$. 303).

Ashley (1970, p. 1088) states that 95 percent of all students attending school will probably never become readers as a matter of habit in later life. The National Commission on Excellence in Education, a federal commission which was appointed by U.S. Secretary of Education Terrel H. Bell, recently released its report, A Nation at Risk: The Imperative for Educational Reform (1983). The results of 18 months of work by the U.S. Department of Education indicated:

Another analyst, Paul Copperman, has drawn a sobering conclusion. Until now, he has noted:

Each generation of Americans has outstripped its parents in education, in literacy, and in economic attainment. For the first time in the history of our country, the educational skills of one generation will not surpass, will not equal, will not even approach, those of their parents.

It is important, of course, to recognize that the average citizen today is better educated and more knowledgable than the average citizen a generation ago--more literate, and exposed to more mathematics, literature, and science. The positive impact of this fact on the well-being of our country and the lives of our people cannot be overstated. Nevertheless, the average graduate of our schools and colleges today is not as welleducated as the average graduate of 25 or 35 years ago, when a much smaller proportion of our population completed high school and college. The 
negative impact of this fact likewise cannot be overstated ( $p$. II).

The findings reported in these studies and the statements made present a challenge to educators. Providing students with stimulating reading materials that are of interest should be of primary concern in view of the potential implications for future reading. A basic educational objective for teachers in the elementary school should be to encourage a love of books by their students. Without an interest in books on the part of the students, the school is hindered in its attempts to teach a program in the fundamentals of reading. Thus, the primary goals of all educators, and especially the library media teachers, is to provide the student with books and materials that are appropriate to the individual's interests, desires, and abilities.

Understanding the basic needs and interests of children and how they relate to the reading process has been one of the goals of reading research. Using a variety of methodological techniques in collecting and analyzing the data, the results suggest several key factors which appear to affect interest in reading: sex, age, reading attainment, and socioeconomic status (Greaney 1980, p. 348). An analysis of these factors suggest that leisure readers tend to be girls who are proficient in reading, middie class, and in the upper elementary grades (Nieuman 19,80, ‥ 333$)$. 
In a recent study (Feeley 1982, p. 15) it was noted that teachers and library media teachers should supply boys with historical-adventure and informational sources, especially in the area of science. These were not, however, favorites with girls. It was felt that exposure for the girls in this area could tend to broaden their reading interests.

Establishing the reading preferences of children remains a valid research topic. Reliable, practical instruments have not, however, been reported (McNinch 1970-71, p. 32; Weintraub 1969, p. 659; and Zimet 1966, p. 124). There is a critical need for a workable student interest inventory at the grass-roots-level of education, one that can be implemented quickly and efficiently by classroom or library media teachers with immediate feedback. This is especially true in light of the research and statistics concerning children's reading habits, preferences, and tastes established in early years (Browman and Templin 1959; Smith 1962; Byers 1964; and Rose, Zimet, and Blom 1972). Many of the current studies point to the problem with these studies of reading interests of children; however, to date no reliable models have been developed (Zimet 1966, p. 124; Weintraub 1969, p. 655. 657, 659; and Tibbetts 1975, p. 503-504).

Sutherland, Monson, and Arbuthnot (1981) point out that "Books are written for children, but adults buy them 
(p. 39)." Editors decide which manuscripts will be accepted and eventually published; reviewers for the national magazines make judgments as to the effectiveness of the books; teachers and librarians exhibit books, read to groups of children and recommend them; and parents and relatives purchase their favorite book for a child. Adults, however, do not know what the desires of the child are unless they ask. Currently there is no tool available for the systematic collection of data and information about asking children what topics are of interest to them. What an adult views as interesting in a specific informational subject or area is not necessarily what a student in the intermediate grades will decide is of interest. As much as possible the professional needs to find what is of interest to the child. Based on that information, in conjunction with the educational and experience background in children's literature, the professional uses available selection tools to help decide what materials should be purchased.

The vast amount of research into children's interests during the past 100 years has indicated a need to determine the basic needs and interests of children and how they relate to the reading process to aid educators in the development of better reading and language arts programs. The literature has also stressed the need for a reliable tool that would allow the collection of data from studies 
of diverse geographical locations, differing intelligence levels, differences of sexes, and from different socioeconomic backgrounds for analysis and comparison to determine overall student interests. The library media center, with its vast array of books and materials, has the means of providing stimulating, interesting books for students. Without a tool for determining student interests, however, the library media teacher is unable to order books and materials that are of interest to the individual and total school population. Neuman (1980) states:

While the identification of correlates of leisure reading has yielded important information regarding subject preferences, it has not significantly contributed to our understanding of the motivations that underlie these preferences nor to the reciprocal, interactive relationship between the reader and the reading material. In addition, potentially important personality variables such as curiosity for learning and the need for information, have generally been overlooked in the research ( $\mathrm{p}$. 333).

Children in the intermediate grades give substantial evidence that they make discriminating judgments about what they like to read and what they dislike reading. This is critical when it is assumed that they learn more readily and effectively as they find interest and appeal in what they are encouraged to do (Coleman and Jungeblut 1961, p. 223). Green (1923) states:

When children read for fun they read because they want to, not because some one else wants them to read. The amount they read for fun depends therefore on how much desire they have for reading and their reading habit. When children read for fun 
they select what they please to read, not what some one else pleases. The quality of reading material which they select is therefore determined directly by their own standards ( $p$. 390).

To date, the researcher has found no studies which have indicated that a correlation exists between student interest in informational or nonfiction literature which is actually checked out of a library media center and measured student interest. It is to this end that this study was conducted.

\section{HYPOTHES IS}

The hypothesis to be tested by this study is:

Null Hypothesis: There is no relationship between the selection of recreational nonfiction books from a school library media center by elementary school students in grades four through six and the measured interest of the students. No significant correlations will be demonstrated.

\section{IMPORTANCE OF THE STUDY}

Most school libraries are organized using the Dewey Decimal Classification system with stacks divided into fiction and nonfiction books. However, many of the reading interest studies do not attempt to delineate between 
fiction and nonfiction. When researchers discuss the types of books that are of interest to children they refer to these books using the general term, literature. Iiterature envelops both fiction and nonfiction, but researchers look at specific literature categories such as adventure, mystery, animal stories, family life stories, biographies, real animals, sports, science, etc., (Ashley 1970, p. 10891091; Chiu 1973, p. 369; Stevens 1981, p. 148-149; and Mangieri 1981, p. 924) to determine interests of students. These terms do not necessarily distinguish between fiction and nonfiction, but they also can be controversial. If they are controversial for adults, they likewise, must be confusing to a student. When the term real animals is utilized it can have different meanings of fiction or nonfiction. It could mean a book dealing with a specific type of animal, or it could refer to a story using real animals as the main characters, such as Mrs. Frisby and the Rats of NIMFH. When the term sports is utilized it also could have several meanings. It could refer to fiction stories that use sports as the setting for the story or it could refer to a book that deals with specific aspects of a sport or sports. With almost all the specific literature headings used by researchers, the student or adult could possibly view the categories as either fiction or nonfiction in most cases. Because of the possible confusion caused by specific literature headings, there is a need to 
distinguish between fiction and nonfiction literature. Since references to nonfiction literature can be nebulous, there is a need for library media teachers to have a tool that can determine interests of students in the area of nonfiction.

Another reason for looking at only the nonfiction area of interest as opposed to the general term, literature, is the fact that students very often state that they like a particular author. These statements are generally concerned with fiction literature. Most of the time the statement put forth is, I like a particular author. Are there any more books by that author? Usually the child can be referred to the collection and the specific author. If books by that author are not found, then it is an easy matter to check catalogs or Books in Print to determine if there are any other materials by that author. If there are books by that author, then books can be ordered for the student's reading pleasure. If a child shows interest in adventure stories by Walt Morey, there are many books available from which to choose. If a child shows interest in the science fiction of John Christopher or Ben Bova, again, there are many books from which to choose. If a child shows interest in Constance Green, Betsy Byars, or Judy Blume, there are many modern fiction books available by these authors also. However, when a child indicates that they like science or history, then the problem is 
what type of science or history. Does the child like science experiments, chemistry, biology, fossils, dinosaurs, colonial American history, world history, ancient history, or what? There are many areas within these disciplines and within each discipline there are many more books available. Thus, there is a need to know specific details concerning nonfiction literature to provide for the needs of the child. Weintraub (1969) states:

The area of children's reading interests remains a vital research concern because of the relevance of reading interests to interest in reading . . . . Carefully executed studies of reading interest.s give teachers, librarians, and other educators a starting point when searching for materials ( $p$. 655).

There are various reasons why researchers have not studied the specific area of nonfiction as opposed to fiction. One possible reason for not studying nonfiction literature is due to the fact that nonfiction is considered by many as a resource material or not as desirable as fiction literature for recreational reading (Greenlaw 1978, p. 498). Since books are classified as fiction or nonfiction Greenlaw feels these books are thought of as not as desirable as fiction. A reviewer of the recently published nonfiction book, Sugaring Time, by Christopher G. Knight, in the May, 1983 issue of School Library Journal, made the following statement:

In lyrical prose and black-and-white photographs, Lasky's book depicts the Lacey family of Vermont making maple syrup. The photos and text combine to make this a rare kind of nonfiction, informative yet as easily read as fiction ( $p$. 73). 
Although there are many nonfiction books that are of excellent quality, many people still view nonfiction as something less desirable than fiction. Mangieri (1981, p. 924-925), in a study conducted of administrators and teachers to determine their knowledge of children's literature, used six areas of literature to facilitate the evaluations. These areas were biography, fantasy/science fiction, mystery, adventure, picture books, and poetry anthologies. It was stated that these areas were not of the author's creation, but rather from authorities in the field of children's literature who maintained that these were six ingredients of a balanced literature program. Biography and poetry anthologies are the only two subject headings that could apply directly to nonfiction, yet these are both considered nebulous areas for nonfiction literature. Thorndike and Henry (1940, p. 756-757), in their use of fictitious, annotated titles, used such headings as realistic animal stories, talking animal stories, rather mild adventures of children, child life in other lands, love and romance, outdoor adventure of boys, mystery and detective stories, school stories, sport stories, etc., to determine interests of children. There are many such examples, but these are excellent inaications that nonfiction literature is often neglected in studies and statements made by experts in the field of children's literature. Apparently educators and some researchers are not aware of the 
vast amount of nonfiction literature that can be used to enhance learning, promote pleasure, and gain knowledge. As Greenlaw (1978, p. 498) points out, the negative connotation given to nonfiction literature might account for the lack of these books being used in most classrooms.

Nonfiction, as an integral part of literature, has much to offer. Some researchers are placing a great deal of importance on nonfiction as a means of developing critical reading skills in areas such as assimilative reading, study-type reading, information, organization, languagesemantics, and versatility. Johnson (1970, p. 213-214) states that an important part of the educational system is to prepare children to become functioning members of society, but the tasks and skills taught in school do not meet the demands that society places on the students when they become adults. Students entering high school usually have not been taught any systematic approaches toward reading and studying factual expository material. In his study summary he states:

The inclusion of much greater amounts of expository material in future reading programs would make more rational the relationship between the reading skills children are expected to acquire and the material through which they are expected to acquire them. It would free narrative fiction from the burden of coercion and permit children to read fiction for pleasure. It would make the reading program more relevant to the demands that society will eventually make of the student at maturity, and possibly produce better quality textbooks in the content areas (p. 215). 
DEFINITION OF TERMS

For the purpose of this report the following terms are defined:

Fiction.--Stories that are created in the minds of the authors and contained in that part of the library assigned as fiction, as determined by cataloging, are considered fiction. These stories would include categories such as modern fiction, historical fiction, science fiction and fantasy, mystery, adventure, and other fictionalized stories.

Fictitious, Annotated Titles.--Fictitious, annotated titles were developed by Thorndike and Henry (1940, p. 751752 ) in order to avoid a situation in which part of the children are reacting on the basis of actual experience with a book, while other children are reacting merely to the general topic set by the title. Annotations were added to the fictitious titles to define the situation somewhat more completely and precisely. An example for a dog adventure story would be the fictitious title, Ionesome Laddy Finds a Friend along with the annotation: how a stray dog found a new master and showed his true love.

Interest.--Interest is defined as strong feelings and curiosity and fascination that a student has toward an activity when the individual is free to choose that activity. It also includes the content, style, and structure of reading materials preferred by students. 
Interest Areas, General.--The general interest areas are those general subject headings that the students indicate on the Student Interest Inventory. An unlimited amount of general interest subject headings can be indicated on the Student Interest Inventory by the students. Interest Areas, Specific.--The specific interest areas are the ten items of most interest to the students as indicated on the Student Interest Inventory. The student can indicate from one to ten specific subject headings but cannot exceed ten subject headings.

Intermediate Grade Students.--Intermediate grade students are considered to be those students in grades four through six.

Library Media Center/Facility.--A library media center or facility is considered to be a school library that includes not only print materials, but also nonprint materials to include such items as filmstrips, $16 \mathrm{~mm}$ films, transparencies, computers, and other materials and items.

Library Media Teacher.--The library media teacher is that person responsible for administering the library media center and its programs, and is also an instructor in such things as research and library skills, promotion of books, reading guidance, and literature enrichment.

Measured Reading Interest.--Measured reading interests are the results obtained from administering the Student Interest Inventory to students to determine reading interests. 
Nonfiction.--Nonfiction is considered primarily

factual literature found in the nonfiction area of the library media center to include such topics as science, social science, biographies, language, and other factual literature. Poetry, folk literature, and jokes and riddles are also included within this area.

Primary Students.--Primary students are considered to be those students in grades one through three.

Reading.--For the purpose of this report this study will accept the definition of reading by Helen Hus (1967) as "the ability to gain the author's meaning from the printed page, to judge its accuracy, quality, and relevancy, and to assimilate and utilize the concepts thus acquired (p. 19)."

\section{ORGANIZATION OF THE STUDY}

The remainder of this study is divided into the following chapters:

Chapter II, A Review of the Literature, is divided into the following sections: Introduction, Reported Methods for Studying Reading Interests, and Findings of Studies Reported in the Literature.

Chapter III, Method of Study, is divided into the following sections: Introduction, Development of the Student Interest Inventory, Dewey Decimal Classification Tens Summary, Method of Correlation, Sample, and Method of Analyzing the Data. 
Chapter IV, Findings of the Study contains the analysis of the data and findings of the research conducted in this study.

Chapter V, Summary, Conclusions, and Recommendations, is divided into those three sections respectively. 


\section{CHAPTER II}

\section{A REVIEW OF THE LITERATURE}

\section{INTRODUCTION}

Studies related to the reading interests of school children have been reported for almost 100 years. Not all studies have been published, however, one of the first published studies appeared in May, 1889, under the title, "What My Pupils Read." In this article, the author, M. B. C. True, acting as librarian for a small school with a population of approximately 175 students, recorded the date of purchase and the number of times a book was selected from the school library during the years 1887 through 1889. No comments or conclusions were drawn from these records by the author, however, he states:

I forebear comment, as each reader can make such comments as the occasion may require. Any one curious, or interested, by equating the time in which each volume has been in the library, can easily ascertain the relative popularity of particular books, and of classes, in this community, among the children attending school (p. 44-45).

Amatora and Edith (1951, p. 134) point out that during the $1890^{\prime}$ 's some seven studies into the reading interest of elementary and secondary school children were conducted. The studies were concerned mainly with 
library withdraws, favorite books of boys and girls, literature and characters that appealed most strongly, and changes in reading interests.

From the turn of the century through 1920 very few studies concerning reading interests were published, however, between 1920 and 1930 studies in the area of reading interests of children increased very rapidly. Traxler and Townsend (1955) in Mackintosh (1957, p. 139) report numerous studies of reading interest at child and adult levels covering the years 1945-1952. During these years, they say, investigators reported little that was new. Teachers rediscovered children's interests in adventure and romance and other facts that had been common kncwledge. Since that time, reading studies of children have continued to increase steadily. Zimet (1966, p. 123) reported that there had been more than 300 studies done on reading. Purves and Beach (1972, p. 173) reported some 360 studies on reading interests to that date and there have been many more since then.

\section{REPORTED IMETHODS FOR STUDYING READING INTERESTS}

A variety of different methods for studying reading interests of children have been reported in the literature. Most of these methods are plagued with the common problems of descriptive or survey research. Problems in reading interest methodology, dissimilar population samples, and 
finaings of investigators being frequently in conflict have been reported by many investigators such as Norvell (1973; p. 4), Weintraub (1969, p. 655), Furves and Beach (1972, p. 61-68), and Tibbetts (1975, p. 503-504). Purves and Beach (1972) made the following generalizations concerning research to date:

Differences in methodology, in addition to differences in type and size of population samples, make it difficult to compare results and thereby generalize about interests. Studies often fail to specify procedures employed. Many early studies lacked the methodological and statistical sophistication of later studies. Many studies focus primarily on what the interests are by means of a checklist, library withdraws, reading inventories, or questionnaires, while others have explored causes of interest patterns by means of case-study methods or measurements which compare the effects of different variables and the relations of these variables to each other. Generalizing about data from different studies is also difficult because of varying assumptions about interests... . Often a clear definition of "interest" is not provided, or certain categories-fiction, nonfiction, reader, nonreader, etc.--are only vaguely defined. . . The most basic problem in methodology is that the instrument used may bias the results (p. 62).

The most popular method of investigation has been the questionnaire (Amatora and Edith 1951, p. 135, and Purves and Beach 1972, p. 62). McKay (Purves and Beach 1972, p. 62) surveyed the literature since 1900 and found that the questionnaire was used twice as often as rating listings and half as often as observations. This method may be used with the children themselves (Witty, Coomer, and McBean 1946, p. 266) or with both the children and the parents to determine the reading tastes and interests of 
the children (Shores 1974, p. 494). The artificiality created by the questionnaire has been noted as one of the problems with this type of testing. The responses can be limited by reactions to books most recently read. It also can be limited due to the fact that the adult investigator may not be drawn by the same element in a category, story, or illustration that attracts a child (Amatora and Edith 1951, p. 135; Weintraub 1969, p. 655; and Purves and Beach 1972, p. 63).

The individual interview or the "oral questionnaire" is another popular research method. Zimet (1966, p. 124) found that a large percent of widely quoted research data was collected by means of interest inventories, questionnaires, or interviews of children. An interview is usually done on a one-to-one basis with the examiner asking questions or presenting materials to the subject. Purves and Beach (1972, p. 63-63) point out that the interview will provide more in-depth information, however, it is very time consuming. Studies have criticized this research technique because the subjects may state what they think will be approved by the adult examiner. Also, studies have found that interviews to ascertain basic interests yield different interests from those revealed by observation records (Young 1955, p. 162; Byers 1964, p. 227; and Zimet 1966, p. 124). The information may also be limited by current readings and not provide long-range information. 
Thorndike (1940, p. 751-752) devised a fictitious title checklist for studying reading interests. Fictitious titles and short annotations describing the content of the book are employed based on the types of reading under investigation. Feeley (1974, p. 225 and 1982, p. Il) also employed an inventory of fictitious, annotated titles based on the Thorndike model. One of the main problems with this type of study is that the types of categories represented may not be clearly distinguished by either, or both, the subject and the examiner.

Another survey technique is one that studies library circulation. Smith (1962) conducted a study with first grade students and Meisel and Glass (1970) conducted a study with fifth graders using this technique. The study of library circulation has its limitations: many books are withdrawn but never read; the availability of materials vary in a given library; and the freedom with which children are permitted to browse through books varies (Amatora and Edith 1951, p. 135; Weintraub 1969, p. 657; and Furves and Beach 1972, p. 65).

A common devise in classroom research is the reading record kept by students or teachers. Young (1955, p. 162), and Amatora and Edith (1951, p. 155) mentioned children's own book records as a useful tool for studying reading interests. Each child would keep a list of the books read during a specified time period. Furves and Beach (1972, 
p. 65) point out that this does provide information about actual reading, but often reading is not fully reported. Also, the record could reflect certain patterns of reading as determined by the availability of books.

Many other types of studies have been employed. Ford and Koplyay (1968, p. 233-234) attempted to measure young children's story preferences by means of a nonverbal instrument. In this study kindergarten and first grade students were asked to circle a picture indicating a story they would most like to read and cross out the picture of the story they wouldn't like to read.

Coleman and Jungeblut (1961, p. 223) had fourth through sixth graders rate selections from trade books. Geeslin and Wilson (1972, p. 751-752) had subjects choose between pairs of pictures. Ashley (1970, p. 1088-1089) had fourth through sixth graders rank topics for reading likes and dislikes.

FINDINGS OF STUDIES REPORTED IN THE IITERATURE

The findings from more than 360 studies provided a wealth of children's reading interests. Some of the findings agreed, but many did not, even at the same grade level. One of the greatest problems encountered in reading reports of children's reading interests in literature is the impossibility of comparing studies because of the diverse methods of investigations involved. The 
studies seem to have few similarities, either of content or of procedure. Norvell (1973) points out:

No two studies have been carried out under the same conditions and by the same methods... there is no means of articulating the results of one study with the results of any other (p. 8).

Evidence that nonfiction categories rate highly in children's interests can be noted in the research compiled by Shores (1954, p. 497-498), Mackintosh (1957, p. 141), Wolfson (1960, p. 82), Byers (1964, p. 232), Ford and Koplyay (1968, p. 235-237), and Stevens (1981, p. 148-149). Shores (1954, p. 494), in studying grades four through eight and Byers (1964, p. 229), in researching grade one, found strong interest in science and nature. Mackintosh (1957, p. 141) noted an interest in real animals and books containing factual information in the primary grades. Ford and Koplyay (1968, p. 235) found interest in history and science in kindergarten through third grade. Stanchfield (1962, p. 42-43) found boys in the first through eighth grades interested in sports, outdoor life, and explorations. Mackintosh (1957, p. 141-142), Stevens (1981, p. 148-149), and Feeley (1982, p. 12-13) found there was a strong interest in factual information in general in elementary age children. Even with the current statistics over the past decade we are still seeing that nonfiction is not used in basal readers or trade books to a great extent (Meisel and Glass 1970, p. 659; Moffet 1982, p. 310; and Moray 1978, p. 767-768). 
Meisel and Glass (1970, p. 655) point out that interest and reading competency are related, thus, reading interests should be studied carefully. If nonfiction literature can aid in this process by motivating students through interest, then it should receive a more prominent place in basal readers and the library media collection. 
METHOD OF STUDY

\section{INTRODUCTION}

The purpose of this study was to ascertain if there is a correlation between the selection of recreational nonfiction books from a school library media center by elementary grade students in grades four through six and the interest of students as measured by a student interest inventory. The study was conducted during the period September, 1982 through April, 1983.

The researcher developed two instruments to collect data for the investigation. One instrument, the Dewey Decimal Classification Tens Summary, was used for keeping records of nonfiction books selected from the school library media center. The other instrument, the student Interest Inventory, was used to determine the interests of the intermediate grade population of the school.

In an attempt to determine if an actual correlation existed between nonfiction recreational books checked out of a library media center and student interest, the study used a population of 164 fourth, fifth, and sixth grade students at Sunnyside Elementary School, North Clackamas 
School District Number 12, Clackamas, Oregon as a sample group.

DEVELOPMENT OF THE STUDENT INTEREST INVENTORY

The development of the Student Interest Inventory was through a four-phase process.

\section{Phase I--Developmental Stage}

For a first draft of the Student Interest Inventory the researcher selected subject headings based on Sears List of Subject Headings (1982). The specific headings were placed in list form. The list was simplified as much as possible using one or two word subject headings placed in alphabetical order (see Appendix A). In an attempt to survey varying districts of different sizes, seven library media teachers throughout the Portland, Oregon-Vancouver, Washington metropolitan area volunteered to aid in the distribution of the first draft. These school districts ranged in size from one elementary school within a district to nineteen elementary schools within a district. The seven contact library media teachers then distributed 65 copies of the first draft to all library media teachers at the elementary level within their respective districts. A cover letter was attached to each draft copy (see Appendix A) asking the library media teachers to evaluate the list based upon their expertise in the field of media 
and children's literature. They were asked to indicate if any items should be deleted, added, or if any items were too vague. Once they had completed their analysis of the list, they were asked to return the list to the researcher along with any comments or suggestions.

\section{Phase II--Iibrary Media Teacher}

\section{Validation Process}

Through the seven contact library media teachers 65 copies of the first draft were distributed. Thirty-nine library media teachers responded to the request for evaluations of the first draft of the Student Interest Inventory or a total of 60 percent responded. When all the first draft copies of the lists were received, the comments by the library media teachers were listed and compiled and revisions were made to the draft list based on those comments and suggestions. The second draft was then written (see Appendix A) and preparations were made to validate the second draft by the use of students within three elementary schools.

\section{Phase III--Student Validation}

\section{Process}

The researcher contacted three elementary schools within varying sized school districts throughout the Portland, Oregon-Vancouver, Washington metropolitan area to participate in the student validation process. At these schools, Portland Christian Elementary School, Portland, 
Oregon (an independent Christian school serving kindergarten through eighth grade), Bilquist Elementary School, Milwaukie, Oregon (one of 19 elementary schools within the North Clackamas School District Number 12), and Felida Elementary School, Vancouver, Washington (one of 9 elementary schools within the Vancouver School District), one classroom teacher and two library media teachers agreed to participate in the student validation process.

The participating teachers met with the researcher and it was explained that the main emphasis of this phase of the validation process was to collect feedback from students concerning the written directions and interest items included on the Student Interest Inventory. The teachers were asked to write down any comments made by students during the validation process, which would then be used to revise the Student Interest Inventory. The teachers were also provided with 100 copies of the Student Interest Inventory to be administered to their students.

The classroom teacher at Bilquist Elementary School administered the Student Interest Inventory to approximately 50 fifth grade students; the library media teacher at Portland Christian Elementary School administered the Student Interest Inventory to approximately 50 fourth, fifth, and sixth grade students; and the library media teacher at Felida Elementary School administered the Student Interest Inventory to approximately 90 fourth, fifth, and sixth grade students. 
The three teachers then provided the researcher with all the comments made by the students during the validation process. Examples of the statements are listed below:

1. Can we check ten items one each page or only ten in all?

2. Does it matter if we put an " $X$ ", or a "?"

3. How many in each category can we check?

4. When you write in a choice, does that count as a choice?

5. If we write in other nonfiction at the bottom of page 3, does that count as one item?

6. Do you have to mark at least one in each category?

7. Does FLOWERS mean growing flowers or does it mean making, drying, and arranging flowers?

8. What does CAREERS/OCCUPATIONS mean?

9. Does MAGIC mean magic tricks?

10. I can't believe that this person didn't include football:

More than half of the students appeared to be frustrated by the fact that they could only mark ten items.

\section{Phase IV--Third and Final}

\section{Draft}

Based on comments and suggestions by the three teachers, the students who responded to the Student Interest Inventory, and faculty members of the Program in Educational Media/Librarianship at Portland State University, a third and final draft was compiled (see Appendix A). By developing the Student Interest Inventory through three phases 
it was felt that most of the possibilities for vague or inaccurate subject headings would be avoided. Requesting advise from many different adult sources also helped to avoid vague and inaccurate items on the Student Interest Inventory by the researcher. Students were used as part of the validation process to make the Student Interest Inventory as easily completed by students as possible.

\section{DEWEY DEC IMAL CLASSIFICATION TENS SUMMARY}

As a means of keeping track of nonfiction materials checked out of the library media center, it was decided to employ a listing of Dewey Decimal Classification Numbers by tens (see Appendix B).

Teachers at the test site, Sunnyside Elementary School, Clackamas, Oregon (one of 19 elementary schools within the North Clackamas School District Number 12), were informed that a test sample of recreational nonfiction book selection by students in grades four through six was being conducted during the school year 1982-1983. They were asked to inform the library media teacher each time they assigned reports or selected nonfiction library readings so that the library media teacher could exclude those books from the sample listings. In this way the sample was free of book choices other than recreational. Since the study was designed for use by intermediate grade students, only those selections made by fourth, fifth, and sixth grade students were counted as part of the sample. 
Each day the nonfiction book selections made by intermediate grade students were tallied; at the end of each week they were again tallied; at the end of each month they were totaled; and at the end of the sampling period they were again totaled for an overview of what recreational nonfiction was actually checked out of the Sunnyside library media center. Monthly totals for November, 1982 were excluded due to clerical error.

\section{METHOD OF CORREIATION}

To be able to correlate the information gathered from the Student Interest Inventories and the Dewey Decimal Tens Summary, Dewey Decimal Classification numbers were assigned to each subject item on the Student Interest Inventory (see Appendix C). These items, where applicable, were clustered together under the Dewey Decimal Tens for evaluation against actual figures from check out totals (see Appendix D).

Since a span of Dewey Decimal Classification numbers was by groups of ten, a problem could possibly arise in areas where different high interest books are contained within the same tens span. Two examples are: the classification 598.1 Reptilia and 599 Mammalia and the classification 001.6 Data Processing, which includes such high interest books as computers and 001.9 Controversial Knowledge which also includes high interest books such as UFOs and related phenomena. This proved to be no problem due 
to the fact that students interested in UFOs and monsters indicated this on the Student Interest Inventory and students interested in computers also indicated this on the Student Interest Inventory. These groupings, such as 001.6 and 001.9 clustered together on the tally sheets, cancelled out any problems. Rather than being a problem, the selections on the respective Student Interest Inventory reflected those areas such as the tens span 590-599, which includes seashells, insects, butterflies and moths, reptiles, birds and mammals, or 620-629, which includes castles and forts, model building, automobiles, trucks, bicycles, motorcycles, space travel, and robots, and could be correlated against high book selection figures found on the Dewey Decimal Classification Tens Summary.

\section{THE SAMPIE}

The sample of student participation for this study consisted of approximately 163 fourth, fifth, and sixth grade students at Sunnyside Elementary School. Sunnyside Elementary School is one of 19 elementary schools within the North Clackamas School District Number 12. Sunnyside has a population of 385 students: 185 girls and 200 boys. Although the school serves a predominately higher socioeconomic area, it is the observation of the researcher that the school population does contain students from all levels of the socioeconomic groups. 
Except for those students absent on the day the Student Interest Inventory was administered, all fourth, fifth, and sixth grade students at Sunnyside Elementary School participated. The sample group consisted of 22 boys and 25 girls in the sixth grades; 31 boys and 25 girls in the fifth grades; and 30 boys and 29 girls in the fourth grades, or a total of 164 students.

\section{METHOD OF ANALYZING THE DATA}

The raw data collected from the Student Interest Inventory and the Dewey Decimal Classification Tens Summary was tabulated and percentages for specific and general interest areas and also for nonfiction books checked out. The specific areas of interest were the ten items the students indicated they would most like to read about. The general areas of interest were those areas the students marked in general. The information was then placed in list form by Dewey Decimal Classification ten spans (see Appendix D). Ratios of nonfiction books checked out compared to the measured interest of specific and general areas were also compiled and compared by Dewey Decimal Classification tens spans and also class spans (see Appendix E). As a means of correlating the raw data for this study, the Pearson's $r$ product-moment correlation formula was employed. This formula required deviation scores, $x$ and $y$, for its application, as well as their squares and their cross products. 
A key to the terms of the formula are included below:

$r$ symbol for Pearson's correlation coefficient

xy: sum of the cross products of the deviation scores

$x^{2}$ : sum of the squared score deviations from the mean of the $\mathrm{X}$ distribution

$\mathrm{y}^{2}$ : sum of the squared score deviations from the mean of the $Y$ distribution

In order to apply the formula the raw data was converted into the required form. A list of the steps involved and the formula are shown below:

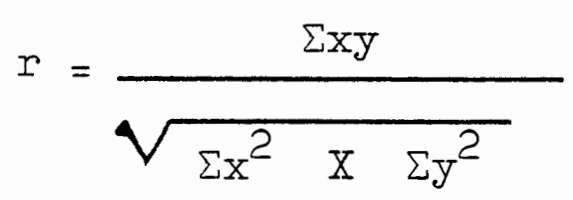

Step 1: Compute the mean for each distribution ( $\bar{X}$ and $\bar{Y}$ )

Step 2: Compute the deviation scores by subtracting the mean of the distribution for each of the raw scores $(\mathrm{X}-\overline{\mathrm{X}}=\mathrm{X} ; \mathrm{Y}-\overline{\mathrm{Y}}=\mathrm{y})$

Step 3: Multiply each $\mathrm{x}$ with its corresponding $\mathrm{y}$ to obtain the cross product (xy)

Step 4: Square each deviation score $\left(x^{2}\right.$ and $\left.y^{2}\right)$

Step 5: Sum the cross products ( $\Sigma x y$ )

Step 6: Sum the squared deviation scores $\left(\Sigma x^{2}\right.$ and $\left.\Sigma y^{2}\right)$

The results of these computations are found in Appendix F. Once the data were transformed to deviations, then substitutes were made to obtain sums in the formula itself. The computations to determine if a correlation exists between student interests and recreational nonfiction books checked out of a library media center were then computed. Figure I 
reflects those computations made to determine correlations between specific interest and books checked out; Figure 2 reflects those computations made to determine correlations between general interests and nonfiction books checked out of the library media center.

$$
\begin{aligned}
r=\frac{\Sigma x y}{\sqrt{\Sigma x^{2} \mathrm{x} \Sigma \mathrm{y}^{2}}} & =\frac{149160.62}{\sqrt{(160046.36)(323570.52)}}= \\
\frac{149160.62}{192930.208} & =.7731
\end{aligned}
$$

Figure 1. Comparison of specific interests and books checked out.

$$
\begin{aligned}
r=\frac{\Sigma x y}{\sqrt{\Sigma x^{2} \mathrm{x} \Sigma \mathrm{y}^{2}}} & =\frac{891500.66}{\sqrt{(959609.81)(937929.32)}}= \\
& \frac{891500.66}{948707.636}=.9397
\end{aligned}
$$

Figure 2. Comparison of general interests and books checked out.

To determine the validity of the two figures, the correlation of the specific interest, .7731, and the correlation of the general interest, .9397 , in relationship to the probability of chance, a $\underline{z}$ test was administered. A null hypothesis stating that the population $R$ is zero was stated, indicating that the $r$ obtained is merely a chance deviation 
in the sampling distribution in which the population $R$ is 0 $\left(\mathrm{H}_{\mathrm{O}}: \mathrm{R}=\mathrm{O}\right)$. The deviation in this case is our obtained $r$; the standard deviation is the standard error of this $r$. To obtain this standard error of the $r$ the formula shown in Figure 3 was used. The actual computations are noted in Figure 4.

$$
\begin{aligned}
\mathrm{S}_{\mathrm{rO}}=\frac{1}{\sqrt{\mathrm{N}-1}} \quad \mathrm{~S}_{\mathrm{rO}} & =\begin{array}{l}
\text { standard error when } \mathrm{R} \text { is } \\
\text { assumed to be } \mathrm{O}
\end{array} \\
\mathrm{N} & =\begin{array}{l}
\text { number of items used in } \\
\text { comparing } \mathrm{r}
\end{array}
\end{aligned}
$$

Figure 3. Formula for the standard error of the r.

1. $\mathrm{S}_{\mathrm{rO}}=\frac{1}{\sqrt{\mathrm{N}-1}}=\frac{1}{\sqrt{37}}=\frac{1}{6.08}=.1645 \mathrm{z}=\frac{.7731}{.1645}=4.70$

2. $\mathrm{S}_{\mathrm{rO}}=\frac{1}{\sqrt{\mathrm{N}-1}}=\frac{1}{\sqrt{37}}=\frac{1}{6.08}=.1645 \mathrm{z}=\frac{.9397}{.1645}=5.71$

$$
\begin{aligned}
& \text { 1. = specific interest } \\
& \text { 2. = general interest }
\end{aligned}
$$

$\frac{\text { Figure 4. }}{\text { of the } r .}$ Computations for the standard error 
CHAPTER IV

FIND INGS OF THE STUDY

As indicated in the first chapter, the purpose of this study was to determine if a correlation existed between the selection of recreational nonfiction books from a library media center by elementary school students in grades four through six and measured interest of the students. The findings concerning this correlation are presented in this chapter.

During the period September, 1982 and April, 1983, a total of 1931 nonfiction books for recreational purposes were checked out of the school library media center. The results of the measured interest of the intermediate grade students reflected a total of 1170 indications of specific interest areas and 3252 indications in general areas. Ratios of nonfiction books checked out to measured interest were also compared by Dewey Decimal Classification tens spans and also class spans. Table I reflects the totals for the specific and general interest areas, books checked out, and ratios for specific and general interest areas. 


\section{TABLE I}

TOTALS OF STUDENT INTEREST INVENTORY SPECIFIC

AND GENERAI AREAS AND BOOKS CHECKED OUT

OF THE IIBRARY MEDIA CENTER

\begin{tabular}{cc|ccc}
\hline \hline Interest Summary & $\begin{array}{c}\text { Books } \\
\text { Checked } \\
\text { Out }\end{array}$ & $\begin{array}{c}\text { Ratio of Books Checked } \\
\text { Out to Specified Interest }\end{array}$ \\
\cline { 4 - 5 } Specific & General & Specific & General \\
\hline 1170 & 3252 & 1931 & 1.7 & .6 \\
\hline
\end{tabular}

The ratios of $1.7: 1$ for specific interest and .6:1 for general interest indicates a relationship between the variables, measured interest compared to books checked out. Since students were restricted to 10 specific items marked on the Student Interest Inventory and unrestricted as to the amount they could mark on the general areas, it was expected that the ratios would be lower for general items. With the exception of the 600 and 900 classes, all class totals indicated a relationship between both general and specific areas of interest and the totals of nonfiction books checked out. The 600 class ratios indicated that both the specific, .9:1 level, and the general, .3:1 level, were under the acceptable levels of 1.0 for specific interests and .5:1 for general interest areas. The two spans within the class, 630-639 and 640-649, showed a relationship for both specific and general interest areas. The 900 class ratios reflected the specific, 1.8 level, to 
be acceptable, but the general interest area, .04:1 level, to be unacceptable. Table II provides the totals and ratios for the two variables, books checked out and specific and general areas of interest.

\section{TABLE II}

TOTAL CLASS RATIOS FOR SPECIFIC AND GENERAL INTEREST AREAS AND BOOKS CHECKED OUT

\begin{tabular}{|c|c|c|c|c|c|}
\hline \multirow{2}{*}{$\begin{array}{c}\text { DDC } \\
\text { Classes }\end{array}$} & \multirow{2}{*}{$\begin{array}{l}\text { Specific } \\
\text { Interest }\end{array}$} & \multirow{2}{*}{$\begin{array}{l}\text { General } \\
\text { Interest }\end{array}$} & \multirow{2}{*}{$\begin{array}{l}\text { Books } \\
\text { Checked } \\
\text { Out }\end{array}$} & \multicolumn{2}{|c|}{$\begin{array}{l}\text { Ratio of Books } \\
\text { Checked Out to } \\
\text { Interest Areas }\end{array}$} \\
\hline & & & & Specific & General \\
\hline $000-009$ & 50 & 126 & 93 & 1.9 & .7 \\
\hline $100-199$ & 26 & 57 & 33 & 1.3 & .6 \\
\hline $200-299$ & 10 & 28 & 32 & 3.2 & 1.1 \\
\hline $300-399$ & 100 & 252 & 155 & 1.6 & .6 \\
\hline $400-499$ & 17 & 38 & 19 & 1.1 & .5 \\
\hline $500-599$ & 116 & 438 & 341 & 3.0 & .8 \\
\hline $600-699$ & 281 & 789 & 259 & .9 & .3 \\
\hline $700-799$ & 491 & 1205 & 642 & 1.3 & .5 \\
\hline $800-899$ & 19 & 74 & 251 & 13.2 & 3.4 \\
\hline $900-999$ & 60 & 245 & 106 & 1.8 & .4 \\
\hline
\end{tabular}

The high interest in class areas 200, 500, 700, and 800 probably account for the types of high interest nonfiction literature found within these areas. In the 200 class, ratio levels of $3.2: 1$ were noted for specific interest and ratio levels of $1.1: 1$ for general interest areas. Within this class, mythology, 290-299, accounted for the high interest with levels of $2.2: 1$ in the specific areas and $1.0: 1$ in the general areas of interest. Although only 
22 books were actually checked out, students indicated interest in this area 10 times on the specific choices and 21 times on general choices. The 500 class, science, also reflected high ratios with $3.0: 1$ being noted in the specific area and $.8: 1$ in the general area of interest. With the exceptions of the tens span, 580-589, trees and flowers, all areas reflected high interest. This indication of high interest in science has been reported throughout the research literature as an area of interest to children at all levels. The 700 class, the arts, also reflected a high interest with ratio levels of $1.3: 1$ and $.5: 1$ being noted in the specific area of interest and general area of interest respectively. The highest area of interest in this class was noted in the tens span, 740-749, drawing, which is of high interest to students in the intermediate grade levels. The 800 class also reflected a high interest with levels in the specific interest area at 13.2:1 and general interest at $3.4: 1$. This is probably accounted for by the fact that jokes and riddles are of high interest and also the poetry books, especially those by Shel Silverstein.

The ratios for the individual Dewey Decimal Classification tens spans and the total group ratios of $1.7: 1$ and .6:1 for the specific and general interest areas suggest a relationship between the two variables, specific and general interest and nonfiction books checked out for recreational reading. The two variables were correlated 
using the Pearson's product-moment correlation formula (the formula and computations are explained in chapter 3). Table III reflects the totals used in these computations.

\section{TABIE III}

TOTAIS OF BOOKS CHECKED OUT AND

SPECIFIC AND GENERAI INTEREST

\begin{tabular}{|c|c|c|c|c|}
\hline \multicolumn{2}{|c|}{ Interest } & \multirow{2}{*}{$\begin{array}{l}\text { Books } \\
\text { Checked } \\
\text { Out }\end{array}$} & $\begin{array}{c}\text { Coefficient of } \\
\text { Sample }\end{array}$ & \multirow{2}{*}{$\begin{array}{l}\text { Cricital } \\
\text { Coefficient }\end{array}$} \\
\hline Specific & General & & Specific General & \\
\hline 1170 & 3252 & 1931 & .940 & .197 \\
\hline
\end{tabular}

The coefficient of .773 for the specific interest area proved to have a significant correlation. The coefficient of .940 for the general interest area proved to have a strong correlation using the ranges of correlation found in Table IV. 
TABLE IV

RANGES OF CORRELATION COEFFICIENTS

\begin{tabular}{ccc}
\hline \hline r & Unexplained Variation & Interpretation \\
\hline o to .5 & $75 \%$ or more & Weak correlation \\
.5 to .7 & $50 \%$ to $75 \%$ & $\begin{array}{c}\text { Moderate correla- } \\
\text { tion } \\
.7 \text { to } .8\end{array}$ \\
.8 to 1.0 & $33 \%$ to $50 \%$ & $\begin{array}{c}\text { Substantial } \\
\text { correlation } \\
\text { Strong correla- } \\
\text { tion }\end{array}$ \\
\hline
\end{tabular}

SOURCE: Taverekere Srikantaiah and Herbert T. Hoffman, An Introduction to Quantitative Research Methods for Libraries, 2nd ed. (Newport Beach, CA: Headway, 1977), p. 77 .

Both coefficients of .773 for the specific interest area and .940 for the general interest area were proved to be significant at the .05 level of confidence. The coefficients were also significant at the .001 level of confidence. Thus, the original null hypothesis was rejected and it was found that there is a correlation between the selection of recreational nonfiction books from a school library by elementary school students in grades four through six and the measured interest of the students. 


\section{CHAPTER V}

SUMMARY, CONCLUSIONS, AND RECOMMEINDATIONS

\section{SUTIMARY}

The purpose of this study was to determine if there was a correlation between the selection of recreational nonfiction books as reflected in circulation statistics from the Sunnyside Elementary School library media center by elementary students in grades four through six and the measured interests of students as reflected through the Student Interest Inventory. It was shown that a correlation does exist between the selection of recreational nonfiction literature and student interests.

The study used a population of all fourth, fifth, and sixth grade students at Sunnyside Elementary School, Clackamas, Oregon, North Clackamas School District Number 12, as a sample group to determine if a correlation actually existed.

Two instruments were developed to aid in this study. One instrument, the Dewey Decimal Classification Tens Summary, was used for keeping records of nonfiction books actually checked out of the library media center. The other instrument was a Student Interest Inventory. The development of the Student Interest Inventory was through 
a four-stage process to make it as teacher and student usable as possible. In this process Bilquist Elementary School, Milwaukie, Oregon; Portland Christian Elementary School, Portland, Oregon; and Felida Elementary School, Vancouver, Washington participated in the validation process for the Student Interest Inventory.

The main statistical analysis used in this study was the Pearson's r to determine correlation coefficients, a $\underline{z}$ test was used to determine chance, and a ratio calculation for determining ratios between interest and nonfiction books checked out of the library media center. The statistical process indicated that a substantial correlation existed at the .7 level of confidence for specific interest and a strong correlation at the .9 level of confidence for general interest in relationship to nonfiction books checked out. Both coefficients were proven to be significant at the .05 and .001 levels of confidence.

\section{CONCLUSIONS}

Several general conclusions can be made from this study despite the limitations of the study: a limited population of 164 students, the availability of books within a single library media center, and groupings of Dewey Decimal Classifications by tens, rather than being more specific. 
The results of the study imply that library media teachers can determine at an individual school the interests of students through the use of the Student Interest Inventory. Once the interests of the students are determined, then this information can be used to further aid the library media teacher in selecting nonfiction literature of interest to the students.

To further aid in the selection of nonfiction literature, the findings of the study also indicate that both the general area of interest as well as the specific area of interest can be determined employing the Student Interest Inventory. This can aid, not only in ordering in specific areas of nonfiction literature, but also in general areas of nonfiction literature. By providing for general areas of interest, those students that indicated a general area of interest as opposed to a specific area, might be inclined to select a book from the shelf if it is available.

\section{RECOMMENDATIONS}

1. A similar study using a larger population would be useful. It would also be beneficial to conduct studies at a wide variety of schools and districts to determine if the Student Interest Inventory could be successfully transferred at other elementary schools, rather than just for a specific school and population. 
2. A similar study employed at a single location for several years to determine if the correlation exists year after year would be useful knowledge.

3. A similar study which subdivided the Dewey Decimal Classifications of high interest areas to determine if greater refinement of the Student Interest Inventory is possible would be very desirable.

4. A study which also compares interests of both boys and girls to determine if it is really necessary to determine reading interests between the sexes would also be useful information.

5. Since reading interests are developed throughout the elementary grades, it would be valuable to refine the Student Interest Inventory and conduct the study in the primary grades to determine their interests in nonfiction literature. 


\section{REFERENCES}

Amatora, S. M. and S. M. Edith. "Children's Interest in Free Reading," School and Society, 73, No. 1889 (195I) , 134-137.

Ashley, I. F. "Children's Reading Interests and Individualized Reading," Elementary English, XIVII (1970, 10881096.

Beta Upsilon Chapter Pi Lambda Theta. "Children's Reading Interests Classified by Age Level," The Reading Teacher, 27 (1974), 694-700.

Brown, Kay Dian and Gerald H. Krockover. "A Reading Preference Test: Rationale, Development, and Implementation," Elementary English, 51 (1974), 1003-1004.

Browman, Margaret Trickey and Mildred C. Templin. "Stories for Younger Children in 1927-29 and 1952-55," The Elementary School Journal, 59 (1959), 324-327.

Byers, Loretta. "Pupil's Interests and the Content of Primary Reading Texts," The Reading Teacher, 17 $(1964), 227-233,240$.

Cappa, Dan. "Kindergarten Children's Spontaneous Responses to Storybooks Read by Teachers," Journal of Educationa? Research, 52 (1958), 75 .

Carr, Jo, comp. Beyond Fact: Nonfiction for Children and Young People. Chicago: American Library Association, 1982 .

Chiu, Lian-Hwang. "Reading Preferences of Fourth Grade Children Related to Sex and Reading Ability," Journal of Educational Research, 66 (1973), 369-373.

Cleary, Florence Damon. Blueprints for Better Learning. New York: H. W. Wilson Co., 1957.

Coleman, J. H. and Ann Jungeblut. "Children's Likes and Dislikes About What They Read," Jounnal of Educational Research, 54 (1961), 223-228.

Dawkins, John. "Defining Fiction and Nonfiction for Students," Lancuage Arts, 54 (1977), 127-129. 
Feeley, Joan T. "Interest Patterns and Media Preferences of Middle-Grade Children," Reading World, XIII (1974), 224-237.

"Content Interests and Media Preferences of Middle-Graders: Differences in a Decade," Reading World, 23 (1982), 11-16.

Fisher, M. Matters of Fact. New York: Crowell, 1972.

Ford, Robin C. and Janos Koplyay. "Children's Story Preferences," The Reading Teacher, 22 (1968), 233-237.

Geeslin, Dorine H. and Richard C. Wilson. "Effect of Reading Age on Reading Interests," Elementary English, XIIX (1972) 750-756.

Greaney, V. "Factors Related to Amount and Type of Leisure Reading Time," Reading Research Quarterly, 25 (1980), $337-357$.

Green, Jenny Lind. "Educational Research and Statistics," School and Society, XVII, No. 432 (1923), 390-392.

Greenlaw, M. Jean. "Information Please: Books and Their Many Uses," Language Arts, 55 (1978), 498-500.

Himmelweit, Hide and Betty Swift. "Continuities and Discontinuities in Media Usage and Taste: A Iongitudinal Study," Journal of Social Issues, 32 (1976), 133-155.

Hurley, Richard J. "Reading Patterns of Children: What and Why They Read." In Reading Interests of Children and Young Adults. Edited by Jean Spealman Kujoth. Meutchen, N.J.: Scarecrow, 1970.

Huus, Helen. Iibraries and Children's Literature in the School Reading Program. Edited by David I. Shepherd. Proceedings of Hofstra University Reading Conferences Four and Five. Vol. II. Hemstead, N.Y.: Hofstra University Press, 1967.

The Quest for Competency in Teaching Reading. Edited by Howard A. Klein. Newark, Delaware: International Reading Association, 1972.

Johnson, Terry D. "Must It Always be the Three Iittle Pigs?" The Reading Teacher, 24 (1970), 209-215.

Kopel, David. "The Nature of Interests," Education, 83 (1963), 497-502. 
Lancaster, Thomas J. "A Story of the Voluntary Reading of Pupils in Grades IV-VIII, "Elementary School Journal, XXVIII (1928), 525-537.

Ianguage Arts Position Papers. An Application of Current Instructional Research and Practices. North Clackamas School District, rev., 1980.

Lasky, Kathryn. Review of Sugaring Time, by Christopher G. Knight, School Library Journal, 29 (1983), 73.

Levy, Terry C. "Getting Kids into Books: The Importance of Individualized Reading," Media \& Methods, 15 (1979), $22-24,26$.

McKay, James. "A Summary of Scientific Research and Professional Literature on Reading Interests." Ph.D. dissertation, University of Pittsburg, 1968, p. 62. In Purves, Alan C. and Richard Beach. Literature and the Reader: Research in Response to Literature, Reading Interests, and the Teaching of Literature. Urbana, IL: National Council of Teachers of English, 1972 .

McNinch, George. "Determining the Reading Preferences of Third, Fourth, and Fifth Grade Disadvantaged Pupils," Journal of Reading Behavior, $3(1970-71), 32-37$.

Mackintosh, Helen K. "Children's Interests in Iiterature and the Reading Program," The Reading Teacher, 10 (1957), 138-143.

Mangieri, John N. "Recreational Reading: Do We Practice What We Preach," The Reading Teacher, 8 (1981), 923-925.

Meisel, Stephen and Gerald G. Glass. "Voluntary Reading Interests and the Interest Content of Basal Readers," The Reading Teacher, 23 (1970), 655-659.

Moffet, J. Bryan. "Student Interest and Pertinence of Content in Selecting Reading Materials," Reading Improvement, 19 (1982), 310-312.

Moray, Geraldine. "What Does the Research Say About the Reading Interests of Children in the Intermediate Grades," The Reading Teacher, 31 (1978), 763-768.

National Society for the Study of Education. Report of the National Committee on Reading. Twenty-Fourth Yearbook, Part I. Chicago: University of Chicago Press, 1925. 
Neuman, Susan B. "Why Children Read: A Functional Approach," Journal of Reading Behavior, XII (1980), 333-336.

"Television Viewing and Leisure Reading: A Qualitative Analysis," Journal of Educational Research, 75 (1982), 299-304.

Norvel1, George W. The Reading Interests of Young People. Ann Arbor, MI: Michigan State University Press, 1973.

O'Brien, Robert C. Mrs. Frisby and the Rats of NIMH. New York: Atheneum, 1975.

Purves, Alan C. and Richard Beach. Literature and the Reader: Research in Response to Literature, Reading Interests, and the Teaching of Literature. Urbana, II: National Council of Teachers of English, 1972.

Rose, Cynthia, Sara G. Zimet, and Gaston E. Blom. "Content Counts, Children Have Preferences in Reading Textbook Stories," Elementary English, XIIX (1972), 14-19.

Rudman, Herbert C. "The Information Needs and Reading Interests of Children in Grades IV Through VIII," Elementary School Journal, IV (1955), 502-512.

Russell, David A. Personal Values in Reading. The Sixtieth Yearbook of the National Scoiety for the Study of Education. Chicago: University of Chicago Press, 1964.

Sears List of Subject Headings. Edited by Barbara M. Westby. 12th ed. New York: H. W. Wilson, 1982.

Shores, J. Harlan. "Reading Interests and Informal Needs of Children in Grades Four to Eight," Elementary English, XXXI (1954), 493-500.

Smith, Ruth C. "Children's Reading Choices and Basic Reader Content," Elementary English, XXXIX (1962), 203-209.

Srikantaiah, Taverekere and Herbert H. Hoffman. An Introduction to Quantitative Research Methods for Libraries. 2nd ed. Newport Beach, CA: Headway, 1977.

Stanchfield, J. M. "Boy's Reading Interests as Revealed Through Personal Conferences," The Reading Teacher, 16 (1962), 41-44.

Stauffer, Russel G. "More Than Words," The Reading Teacher, $12(1958), 29$. 
Stevens, Kathleen C. "Reading Interests Among Fifth and Sixth Grade Children," Reading Horizons, 21 (1981), 147-150.

Sutherland, Zena, Dianne I. Monson, and May Hill Arbuthnot. Children and Books. '6th ed. Greenville, II: Scott, Foresman, 1981.

Thorndike, Robert I., and Florence Henry. "Differences in Reading Interests Related to Differences in Sex and Intelligence Levels," Elementary English, XI (1940), $751-763$.

Tibbetts, Sylvia-Lee. "Research in Childrens Literature: A Need for Standardized Procedures," Elementary English, 52 (1975), 503-504.

Traxler, Arthur E. and Agatha Townsend. Eight More Years of Research in Reading. New York: Educational Records Bureau, 1955, p. 283. Cited by Helen K. Mackintosh, "Children's Interests in Iiterature and the Reading Program," The Reading Teacher, 10 (1957), 138-143.

True, M. B. C. "What My Pupils Read," Education, X (1889), $42-45$.

U.S. Department of Education. A Nation at Risk: The Imperative for Educational Reform. The National Commission on Excellence in Education. Washington, D.C.: General Printing Office, 1983.

Weintraub, Samuel. "Research: Children's Reading Interests," The Reading Teacher, 22 (1969), 655- 657, 659.

Witty, Paul. "Children of the Television Era," Elementary English, 44 (1967), 538-535.

"Interest, Effort and Success--Bases for Effective Reading," Education, 79 (1959), 480-486. et al. A Study of the Interests of Children and Youth. ERIC $002846,1959$.

Ann Coomer, and Dilla McBean. "Children's Choices of Favorite Books: A Study Conducted in Ten Elementary Schools," Journal of Educational Psychology, XXXVII (1946), 266-278.

Wolfson, Bernice J. "What Do Children Say Their Reading Interests Are?" The Reading Teacher, 14 (1960), 82-82. 
World Book Dictionary. 1973 ed.

Young, Doris. "Identifying and Utilizing Children"s Interests," Educational Leadership, XIII (1955), 161-165.

Zimet, Sara F. "Children's Interests and Story Preferences: A Critical Review of the Literature," Elementary School Journal, 67 (1966), 123-129. 
APPENDIX A

COVER IETTER AND STUDENT INTEREST INVENTORY, DRAFTS 1, 2, AND 3 
COVER IETTER

Library Media Teacher:

As part of my Master's thesis at Portland State University, I am attempting to validate a Student Interest Inventory. This inventory will be used in conjunction with the selection of recreational nonfiction reading by students. I am attempting to find if there is a correlation between student interest in nonfiction subject areas and books actually checked out of a library media center. This interest inventory will be used with fourth, fifth, and sixth grade students here at Sunnyside Elementary School, North Clackamas School District Number 12, Clackamas, Oregon.

Approximately 50 library media teachers will be looking at this sample Student Interest Inventory in an attempt to validate it. Each library media teacher will be asked to look at the Interest Inventory and see if there are areas that need to be added, deleted, or changed to make this a useful student tool.

Once the Student Interest Inventory is validated by library media teachers, it will then be administered to a pilot group of approximately 40 fourth, fifth, and sixth grade students to further validate it as a workable student library tool.

Would you now please take time to look at the attached copy of the proposal and see if you have any suggestions that might help in this validation. Check the areas of interest. If you think some are not valid, cross them out. If you feel some are vague, so indicate. If you feel additional areas of interest need to be added, indicate this also. If you have any suggestions or comments, please indicate these at the bottom of the proposed Student Interest Inventory.

Once you have finished, would you please return the proposed Student Interest Inventory to me at Sunnyside Elementary School, North Clackamas School District Number 12 , 13401 S. E. 132nd Ave., Clackamas, Oregon, 97015, Attention: Library--Leedy.

Thank you for your help. Your efforts will be much appreciated in validating this student Interest Inventory.

Thank you,

Larry C. Leedy

Library Media Teacher

Sunnyside Elementary School 


\section{DRAFT 1}

\section{INTEREST INVENTORY}

We, in the library, would like to know what type of nonfiction books you like to read. Please take time in looking at this sheet and marking the kind of reading you enjoy, so we can purchase books which will have a special appeal just for you.

DIRECTIONS: Read the list carefully. Read the list a second time and place a check by 10 types of nonfiction books that you would enjoy reading.

TYPES OF NONFICTION (FACTUAL) BOOKS:

—ACTING

- AIRPIIANES

_ AN IMALS

AQUARIUMS

ARMS \& ARMOR

ART

ASTRONOMY

AUTOMOBILES

BALLET

BASEBALI

BASKETBALL

BICYCLES

BIOGRAPH IES

BIOLOGY

BIRDS

BOATS \&

BOAT ING

BUTTERFIIES

\& MOTHS

CAMPING

CARE OF

AN IMALS
_CATS

— CAVES

_CERAMICS

_CHEMISTRY

CIPHERS \&

CODES

- COIN

COLIECTING

_ COMPUTERS

_ COOKING

COSTUMES

_COWBOYS

CROCODIIES \&

ALIIGATORS

_DANCING

—DINOSAURS

_DOGS

DRAGONS

DRAWING

FAIRY TAIES

FISH
FISH ING FLOWERS FLYING SAUCERS FOOTBALL FOSS ILS GAMES GEOGRAPHY GEOLOGY HISTORY HOBBIES HOCKEY

HORSEBACK RIDING

_HORSES HUNT ING ICE SKATING IND IANS JOKES \& RIDDIES

_MAGIC

— MARINE ANIMALS MONKEYS 
- MOTORCYCIES

MUS IC

MUS ICAL

INSTRUMENTS

_MYTHOLOGY

- NATURE STUDY

OCEANOGRAPHY

PAINT ING

PETS

PHOTOGRAPHY

PLAYS
POETRY

PUPPETS

RELIGION

REPT ILES

ROBOTS

ROCKETS

ROCKS \&

MINERAIS

SECRET CODES

SPACE FLIGHT

SPACESHIPS
STARS

SUBMARINES

SW IMIIING

_OTHER (If you did not find the type of nonfiction book you especially enjoy on this list, please write that kind of book here:) 


\section{DRAFT 2}

\section{INTEREST INVENTORY}

To provide you, the student, with library books you enjoy, we would like to know what type of nonfiction books you like to read. REMEMBER, nonfiction books are "factual" or "true" books and are those books with Dewey Decimal

Numbers as part of the call number. Please take your time in looking over this Interest Inventory and mark the type of nonfiction reading you enjoy.

DIRECTIONS: Read over the list carefully the first time. Read the list a second time and place a check by up to 10 types of nonfiction books that you enjoy reading.

\section{TYPES OF NONFICTION (FACTUAL) BOOKS:}

\section{A IRPLANES}

ANIMALS, WIID:

Alligators \& Crocodiles

Bears

Beavers

Chipmunks \& Squirrels

Cougars (Mountain Lions)

Elephants

Foxes \& Wolves

Frogs \& Toads

Giraffes

Lions \& Tigers

Lizards \& Salamanders

Monkeys \& Apes

Porpoises \& Do $\overline{l p h i n s}$

Snakes

Whales

Others:

AQUARIUMS

ARMS \& ARMOR
ART :

Drawing

Painting

ASTRONOMY :

Moons

Planets

Stars

AUTOMOBIIES (Cars)

BAILET

BICYCLES

BIOGRAPHIES (Stories about famous people)

Name some you would like to read about:

BIRDS

BOATS, BOATING, \& SHIPS 
BUTTERFIIES \& MOTHS

CAMPING

CARE OF PETS \& ANIMALS:

Birds

Cats

Dogs

Gerbils, Guines Pigs, \& Hamsters

Horses

Rabbits

Others:

CAREERS/OCCUPAT IONS

CASTLES \& FORTS

CAVES

CERAMICS \& POTTERY

CHEMISTRY

CHESS

CIPHERS, CODES, \& SECRET MESSAGES

COIN COILECTING

COMPUTERS

COOK ING

COSTUMES

COWBOYS

CRAFTS (Making Things)

DANCING

DINOSAURS

DRAGONS

ELECTRICITY
FEEIINGS (Getting along with others )

FIRST AID

FISH ING

FLOWERS

FOIKTALES :

Fables

Fairy Tales

Legends

Myths

Tall Tales

FOREIGN IANGUAGES

FOSS IIS

GAMES

GARDEN ING

GEOGRAPHY :

Countries

Maps \& Globes

States

GEOLOGY (Rocks \& Minerals)

GHOSTS

GUINESS WORID RECORDS

GYMNASTICS

HEAITH

HISTORY :

American History

Colonial American History

World History Other:

HOIIDAYS

HORSES \& HORSEBACK RIDING 
HUMAN BODY

HUNT ING

INSECTS

IND IANS

JOKES \& RIDDLES

KEEPING FIT (Aerobics \& Exercise)

MAGIC

MARTIAL ARTS

MODEL BUILDING :

Airplanes

Boats

Cars

Trains

Other:

MONSTERS

MOTORCYCLES \&

DIRTBIKES

MOVIES \& T.V.

MUSICAL INSTRUMENTS

OCEANS

PHOTOGRAPHY

PLAYS

POETRY

PRES IDENTS

PUPPETS

RAC ING :

Cars

Dirtbikes

Motocross
Motorcycles

OTHER :

- RELIGION

ROBOTS

SC IENCE EXPERIMENTS

SEASHORE ANIMAIS

SEASHELIS

SEWING

SONG BOOKS

SPACE TRAVEI

SPORTS :

Baseball

Basketball

Hockey

Ice Skating

Racquetball

Running

Skiing

Soccer

Swimming

Tennis

Volleyball

Weight Lifting

Other:

STAMP COLIECTING

TRA INS

TREES

TRUCKS

TRUE ADVENTURE 
WEAPONS \& WAR:

Airplanes

Guns

Submarines

Tanks

World War I

World War II

Korean War

Vietnamese War

Other:

WEATHER

WOODCRAFTS

UFO'S

VOLCANOES

If there are other nonfiction books you like, but they are not on this list, please list them below:

1 .

2 .

3 . 


\section{DRAFT 3}

STUDENT INTEREST INVENTORY

To provide you, the student, with library books you enjoy, we would like to know what type of nonfiction books you like to read. REMEMBER, nonfiction books are "factual" or "true" books and are those books with Dewey Decimal

Numbers as part of their call number. Please take your time in looking over this Interest Inventory and mark the type of nonfiction reading you enjoy.

DIRECTIONS: Read over the list carefully the first time.

Mark all the subject areas that are of interest to you. Read the list a second time and circle up to 10 subject items that interested you the most.

\section{TYPES OF NONFICTION (FACTUAL) SUBJECTS}

AIRPIANES

AN IMALS, WILD :

Alligators \& Crocodiles

Bears

Beavers

Chipmunks \& Squirrels

Cougars (Mountain Iions) Elephants Foxes \& Wolves

Frogs \& Toads

Giraffes

Iions \& Tigers

Iizards \& Salamanders

Monkeys \& Apes

Porpoises \& Dolphins

Snakes

Whales

ARMS \& ARMOR

ART :

Drawing

Painting

ASTRONOMY :

Moons

Planets

Stars
AUTOMOBIIES (Cars)

BAIIET

BICYCLES

BIOGRAPHIES (Stories about famous people)

BIRDS

BOATS \& BOATING

BUTTERFLIES \& MOTHS

CAMPING

CARE OF AN IMALS Birds

Cats

Dogs

Horses

Rabbits

CAREERS/OCCUPATIONS

CASTLES \& FORTS 
CAVES

CERAMICS \& POTTERY

CHEMISTRY

CHESS

CIPHERS, CODES, \& SECRET MESSAGES

COIN COLLECTING

COMPUTERS

COOKING

COSTUIMES

COWBOYS

CRAFTS (Making Things )

DANC ING

DINOSAURS

DRAGONS

EIECTRICITY

EXERC IS ING

FEELINGS (Getting

along with others)

FIRST AID

FISHING

FLOWERS

FOLKTALES

FOREIGN IANGUAGES

FOSSIIS

GARDEN ING
GEOGRAPHY :

Countries

Maps \& Globes

States

GEOLOGY (Rocks \& Minerals) GHOSTS

GUINESS WORID RECORDS

GYMINASTICS

HEALTH

HISTORY :

American History Colonial American History World History

HOLIDAYS

HORSEBACK RIDING

HUMAN BODY

HUNT ING

INDIANS

INSECTS

JOKES \& RIDDLES

MAGIC

MODEL BUIIDING:

Airplanes

Boats

Cars

Trains

MONSTERS

MOTORCYCIES \& DIRTBIKES

MOVIES \& TV

MUS ICAL INSTRUMENTS

MYTHS 
OCEANS

PHOTOGRAPHY

PLAYS

POETRY

PRES IDENTS

PUPPETS

RAC ING :

Cars

Dirtbikes

Motocross

Motorcycles

RELIGION

ROBOTS

SC IENCE EXPERIMENTS

SEASHEIIS

SEWING

SONG BOOKS

SPACE TRAVEI

SPIDERS

SPORTS :

Baseball

Basketball

Football

Hockey

Ice Skating

Running

Skiing

Soccer

Swimming

Tennis

Voll eyball

STAMP COILECTING

TRAINS
TREES

TRUCKS

VOLCANOES

WEAPONS OF WAR \& WAR Submarines

Tanks

World War I World War II Korean War Vietnamese War

WEATHER

WOODCRAFTS

If there are other nonfiction subjects you like to read about, but did not find them on this list, please list those items below: 
APPENDIX B

DEWEY DEC IMAL TENS SUMMARY WORKSHEET 


\section{DEWEY DECIMAL TENS SUMMARY WORKSHEET}

WEEK OF

WEEK OF

\begin{tabular}{|c|c|c|c|c|c|c|c|c|c|c|c|c|}
\hline & MON & TUE & WED & THU & FRI & TOTAI & MON & TUE & WED & THU & FRI & TOTAI \\
\hline $000-009$ & & & & & & & & & & & & \\
\hline $010-019$ & & & & & & & & & & & & \\
\hline $020-029$ & & & & & & & & & & & & \\
\hline $030-039$ & & & & & & & & & & & & \\
\hline $040-049$ & & & & & & & & & & & & \\
\hline $050-059$ & & & & & & & & & & & & \\
\hline $060-069$ & & & & & & & & & & & & \\
\hline $070-079$ & & & & & & & & & & & & \\
\hline $080-089$ & & & & & & & & & & & & \\
\hline $090-099$ & & & & & & & & & & & & \\
\hline $100-109$ & & & & & & & & & & & & \\
\hline $110-119$ & & & & & & & & & & & & \\
\hline $120-129$ & & & & & & & & & & & & \\
\hline $130-139$ & & & & & & & & & & & & \\
\hline $140-149$ & & & & & & & & & & & & \\
\hline $150-159$ & & & & & & & & & & & & \\
\hline $160-169$ & & & & & & & & & & & & \\
\hline $170-179$ & & & & & & & & & & & & \\
\hline $180-189$ & & & & & & & & & & & & \\
\hline $190-199$ & & & & & & & & & & & & \\
\hline $200-209$ & & & & & & & & & & & & \\
\hline $210-219$ & & & & & & & & & & & & \\
\hline $220-229$ & & & & & & & & & & & & \\
\hline $230-239$ & & & & & & & & & & & & \\
\hline $240-249$ & & & & & & & & & & & & \\
\hline $250-259$ & & & & & & & & & & & & \\
\hline $260-269$ & & & & & & & & & & & & \\
\hline $270-279$ & & & & & & & & & & & & \\
\hline $280-289$ & & & & & & & & & & & & \\
\hline $290-299$ & & & & & & & & & & & & \\
\hline $300-309$ & & & & & & & & & & & & \\
\hline $310-319$ & & & & & & & & & & & & \\
\hline $320-329$ & & & & & & & & & & & & \\
\hline $330-339$ & & & & & & & & & & & & \\
\hline $340-349$ & & & & & & & & & & & & \\
\hline $350-359$ & & & & & & & & & & & & \\
\hline $360-369$ & & & & & & & & & & & & \\
\hline $370-379$ & & & & & & & & & & & & \\
\hline
\end{tabular}


WEEK OF

WEEK OF

\begin{tabular}{|c|c|c|c|c|c|c|c|c|c|c|c|c|}
\hline & MON & TUE & WED & THU & FRI & TOTAL & |MON| & TUE & WED & THU & FRI & TOTAI \\
\hline \multicolumn{13}{|c|}{$380-389$} \\
\hline \multirow{2}{*}{\multicolumn{13}{|c|}{$\frac{390-399}{400-409}$}} \\
\hline & & & & & & & & & & & & \\
\hline \multicolumn{13}{|l|}{$410-419$} \\
\hline \multirow{2}{*}{\multicolumn{13}{|c|}{$\frac{420-429}{430-439}$}} \\
\hline & & & & & & & & & & & & \\
\hline \multicolumn{13}{|l|}{$440-449$} \\
\hline \multicolumn{13}{|l|}{$450-459$} \\
\hline \multicolumn{13}{|l|}{$\frac{460-469}{470-479}$} \\
\hline \multirow{2}{*}{\multicolumn{13}{|c|}{$\frac{470-479}{480-489}$}} \\
\hline & & & & & & & & & & & & \\
\hline \multicolumn{13}{|l|}{$490-499$} \\
\hline \multicolumn{13}{|l|}{$500-509$} \\
\hline \multirow{2}{*}{\multicolumn{13}{|c|}{$\frac{510-519}{520-529}$}} \\
\hline & & & & & & & & & & & & \\
\hline \multicolumn{13}{|l|}{$530-539$} \\
\hline \multirow{2}{*}{\multicolumn{13}{|c|}{$\frac{540-549}{550-559}$}} \\
\hline & & & & & & & & & & & & \\
\hline \multicolumn{13}{|l|}{$560-569$} \\
\hline \multicolumn{13}{|l|}{$570-579$} \\
\hline \multicolumn{13}{|l|}{$580-589$} \\
\hline \multirow{2}{*}{\multicolumn{13}{|c|}{$\frac{590-599}{600-609}$}} \\
\hline & & & & & & & & & & & & \\
\hline \multicolumn{13}{|l|}{$610-619$} \\
\hline \multirow{2}{*}{\multicolumn{13}{|c|}{$\frac{620-629}{630-639}$}} \\
\hline & & & & & & & & & & & & \\
\hline $640-649$ & & & & & & & & & & & & \\
\hline $650-659$ & & & & & & & & & & & & \\
\hline $660-669$ & & & & & & & & & & & & \\
\hline $670-679$ & & & & & & & & & & & & \\
\hline $680-689$ & & & & & & & & & & & & \\
\hline $690-699$ & & & & & & & & & & & & \\
\hline $700-709$ & & & & & & & & & & & & \\
\hline $710-719$ & & & & & & & & & & & & \\
\hline $220-729$ & & & & & & & & & & & & \\
\hline $730-739$ & & & & & & & & & & & & \\
\hline $740-749$ & & & & & & & & & & & & \\
\hline $750-759$ & & & & & & & & & & & & \\
\hline $760-769$ & & & & & & & & & & & & \\
\hline $270-779$ & & & & & & & & & & & & \\
\hline $780-789$ & & & & & & & & & & & & \\
\hline $290-799$ & & & & & & & & & & & & \\
\hline $800-809$ & & & & & & & & & & & & \\
\hline $810-819$ & & & & & & & & & & & & \\
\hline $820-829$ & & & & & & & & & & & & \\
\hline $830-8391$ & & & & & & & & & & & & \\
\hline
\end{tabular}


WEEK OF WEEK OF

\begin{tabular}{|c|c|c|c|c|c|c|c|c|c|c|c|c|}
\hline \multirow{2}{*}{$840-849$} & $\overline{M O N}$ & TUE & WED & THU & $\overline{\text { FRI }}$ & TOTAI & MON & TUE & WED & THU & FRI & TOTAL \\
\hline & & & & & & & & & & & & \\
\hline $850-859$ & & & & & & & & & & & & \\
\hline $860-869$ & & & & & & & & & & & & \\
\hline $870-879$ & & & & & & & & & & & & \\
\hline $880-889$ & & & & & & & & & & & & \\
\hline $890-899$ & & & & & & & & & & & & \\
\hline $900-909$ & & & & & & & & & & & & \\
\hline $910-919$ & & & & & & & & & & & & \\
\hline $920-929$ & & & & & & & & & & & & \\
\hline $930-939$ & & & & & & & & & & & & \\
\hline $940-949$ & & & & & & & & & & & & \\
\hline $950-959$ & & & & & & & & & & & & \\
\hline $960-969$ & & & & & & & & & & & & \\
\hline $970-979$ & & & & & & & & & & & & \\
\hline $980-989$ & & & & & & & & & & & & \\
\hline $990-999$ & & & & & & & & & & & & \\
\hline
\end{tabular}




\section{APPENDIX C}

DEWEY DECIMAL CLASSIFICATION NUMBERS AND SUBJECT HEAD INGS 
DEWEY DECIMAI CLASSIFICATION NUMBERS AND SUBJECT HEADINGS

\section{DEWEY DECIMAL NUMBERS} (DDC)

001.6

001.9

032

133.1

152.4

200

331.7

351.003

353.03

355.8

358.18

359.3

385

387.7

391

398

398.2

400

507

523

537

540

550

551.21

551.46

551.6

560
SUBJECT HEADINGS

COMPUTERS

UFO'S

GUINESS WORLD RECORD BOOKS

GHOSTS

FEELINGS

RELIGION

CAREERS/OCCUPAT IONS

PRES IDENTS

PRES IDENTS

ARMS \& ARMOR

TANKS

SUBMARINES

TRAINS (RAILROADS)

AIRPIANES

COSTUMES

FOIKTALES; MONSTERS

FOIIKTAIES; DRAGONS

FOREIGN IANGUAGE

SCIENCE EXPERIMENTS

ASTRONOMY

ELECTRICITY

CHEMISTRY

GEOLOGY

VOLCANOES

OCEANS

WEATHER

FOSS ILS 
DDC NO.

567.9

568.1

582

582.16

594

595.4

595.7

595.78

598.1

598.2

599

611

612

613

613.7

614.8

616

616.02

621.3

623.1

623.4

623.8

623.82

625.1

625.19

629.133

629.221
SUBJECT HEADINGS

\section{INOSAURS}

(Old listing for DINOSAURS)

FLOWERS

TREES

SEASHELIS

SPIDERS

INSECTS

BUTTERFIIES \& MOTHS

REPTILES (Alligators \& Crocodiles; Frogs \& Toads; Lizards \& Salamanders; and Snakes)

BIRDS

MAMTAIS (Bears; Beavers; Chipmunks \&

Squirrels; Cougars; Elephants;

Foxes \& Wolves; Giraffes; Lions

\& Tigers; Monkeys \& Apes;

Porpoises \& Dolphins; and Whales

HUIMAN BODY

HUMAN BODY

HEALTH

KEEPING FIT

(Old class for First Aid)

HEAITH

FIRST AID

ELECTRICITY

CASTLES \& FORTS

ARMS \& ARMOR

SUBMARINES

MODEI BUILDING, BOATS

TRAINS, (RAIIROADS)

MODEL BUIIDING, TRAINS

MODEI BUIIDING, AIRPLANES

MODEL BUIIDING, CARS 


\begin{tabular}{|c|c|}
\hline DDC NO. & SUBJECT HEADINGS \\
\hline 629.222 & AUTOMOBILES（CARS） \\
\hline 629.223 & TRUCKS \\
\hline 629.2272 & BICYCLES \\
\hline 629.2275 & MOTORCYCLES \\
\hline 629.4 & SPACE TRAVEL \\
\hline 629.8 & ROBOTS \\
\hline 635 & GARDEN ING \\
\hline 636 & CARE OF ANIMALS, RABBITS \\
\hline 636.1 & CARE OF ANIMALS, HORSES \\
\hline 636.6 & CARE OF ANIMALS, BIRDS \\
\hline 636.7 & CARE OF ANIMALS, DOGS \\
\hline 636.8 & CARE OF ANIMALS, CATS \\
\hline 641.5 & COOKING \\
\hline 646 & SEW ING \\
\hline 652 & CIPHERS \& CODES \\
\hline 666 & CERAMICS \& POTTERY \\
\hline 728.8 & CASTIES \& FORTS \\
\hline 736 & WOODCRAFTS \\
\hline 737.4 & COIN COLIECTING \\
\hline 738 & CERAMICS \& POTTERY \\
\hline 739.7 & ARMS \& ARMOR \\
\hline 741 & DRAWING \\
\hline 742 & DRAW ING \\
\hline 743 & DRAWING \\
\hline 745 & CRAFTS \\
\hline 751 & PAINT ING \\
\hline 759.56 & STAMP COLLECTING \\
\hline 770 & PHOTOGRAPHY \\
\hline 781.91 & MUSICAL INSTRUMENTS \\
\hline 784.6 & SONG BOOKS \\
\hline 790 & PLAYS \\
\hline
\end{tabular}


DDC NO.

791.4

791.5

792.8

793.3

793.8

794.1

796.32

796.323

796.332

796.334

796.342

796.357

796.4

796.54

796.426

796.72

796.75

796.8

796.9

796.91

796.96

797.1

797.2

798.2

799.1

799.2

808.7

808.8

808.81

811.08

817

909
SUBJECT HEADINGS

MOVIES \& TV

PUPPETS

BAIILET

DANCING

MAGIC

CHESS

VOLIEYBAII

BASKETBAII

FOOTBAIL

SOCCER

TENNIS

BASEBAII

GYMNASTICS; EXERCISES

CAMPING

RUNN ING

RACING; CARS

RACING; MOTORCYCIES

MARTIAI ARTS

SKIING

ICE SKATING

HOCKEY

BOATS \& BOATING

SW IMM ING

HORSEBACK RIDING

FISHING

HUNTING

JOKES \& RIDDIES

JOKES \& RIDDIES

POETRY

POETRY

JOKES \& RIDDLES

WORID HISTORY 


\begin{tabular}{ll}
\hline DDC NO. & SUBJECT HEADINGS \\
\hline 910 & GEOGRAPHY \\
917.8 & COWBOYS \\
921 & BIOGRAPHIES \\
940.03 & W.W. I \\
940.53 & W.W. II \\
951.9 & KOREAN WAR \\
959.704 & VIETNAMESE WAR \\
970 & AMERICAN HISTORY \\
970.1 & INDIANS \\
973 & AMERICAN HISTORY \\
973.2 & COLONIAI AMERICAN HISTORY
\end{tabular}


DEWEY DECTMAL CLASSIFICATION NUMBERS AND SUBJECT HEADING CLUSTERS

DDC NO. SPAN BY TENS
SUBJECT HEADINGS

COMPUTERS; UFOS

GUINESS WORLD RECORD BOOKS

GHOSTS

FEELINGS

RELIGION

MYTHOLOGY

CAREERS/OCCUPATIONS

PRESIDENTS; ARMS \& ARMOR; TANKS

TRAINS; AIRPIANES

COSTUMES; FOLKTALES; DRAGONS; MONSTERS

FOREIGN IANGUAGE

SCIENCE EXPERIMENTS

ASTRONOMY

ELECTRICITY

CHEMISTRY

GEOLOGY; VOLCANOES; OCEANS; WEATHER FOSSILS; D INOSAURS

FLOWERS; TREES

SEASHELIS; INSECTS; BUTTERFIIES \& MOTHS; MAMMALS; REPTILES; BIRDS;

$610-619$ $620-629$

$630-639$

$640-649$

$650-659$

$660-669$
HEAITH; HUMAN BODY; FIRST AID; KEEPING FIT ELECTRICITY; CASTLES \& FORTS; ARMS \& ARMOR; MODEL BUILDING; AUTOMOBILES; TRUCKS; SPACE TRAVEI; ROBOTS; MOTORCYCLES; TRAINS; SUBMARINES; BICYCLES

GARDENING; CARE OF ANIMALS

COOKING; SEWING

CIPHERS, CODES, \& SECRET MESSAGES

CERAMICS \& POTTERY 


\begin{tabular}{ll} 
DDC NO; & SUBJECT HEADING \\
SPAN BY TENS & \\
\hline $720-729$ & CASTLES \& FORTS \\
$730-739$ & WOODCRAFTS; ARMS \& ARMOR; CERAMICS \& \\
& POTTERY; COIN COIIECTING \\
$740-749$ & DRAWING; CRAFTS \\
$750-759$ & PAINTING; STAMP COIIECTING \\
$770-779$ & PHOTOGRAPHY \\
$780-789$ & MUSICAI INSTRUMENTS; SONG BOOKS \\
$790-799$ & PLAYS; MOVIES \& TV; PUPPETS; BAIIET; \\
& DANCING; MAGIC; CHESS; SPORTS; MARTIAI \\
& ARTS; RACING; GYMNASTICS; EXERCISING; \\
BOATS \& BOATING; SWIMIING; HORSEBACK & RIDING; FISHING; HUNTING \\
$900-909$ & JOKES \& RIDDIES; POETRY \\
$920-929$ & WORID HISTORY \\
$940-949$ & BIOGRAPHIES \\
$950-959$ & WORID WAR I; WORID WAR II \\
$970-979$ & KOREAN WAR; VIETNAMESE WAR \\
& AMERICAN HISTORY; INDIANS; COLONIAL \\
& AMERICAN HISTORY
\end{tabular}


APPENDIX D

SUMMARY OF CLASSIFICATION NUMBERS AND SUBJECT HEADINGS, AND CLASSIFICATION NUMBERS AND SUBJECT HEADING CIUSTERS SUTMIARY 


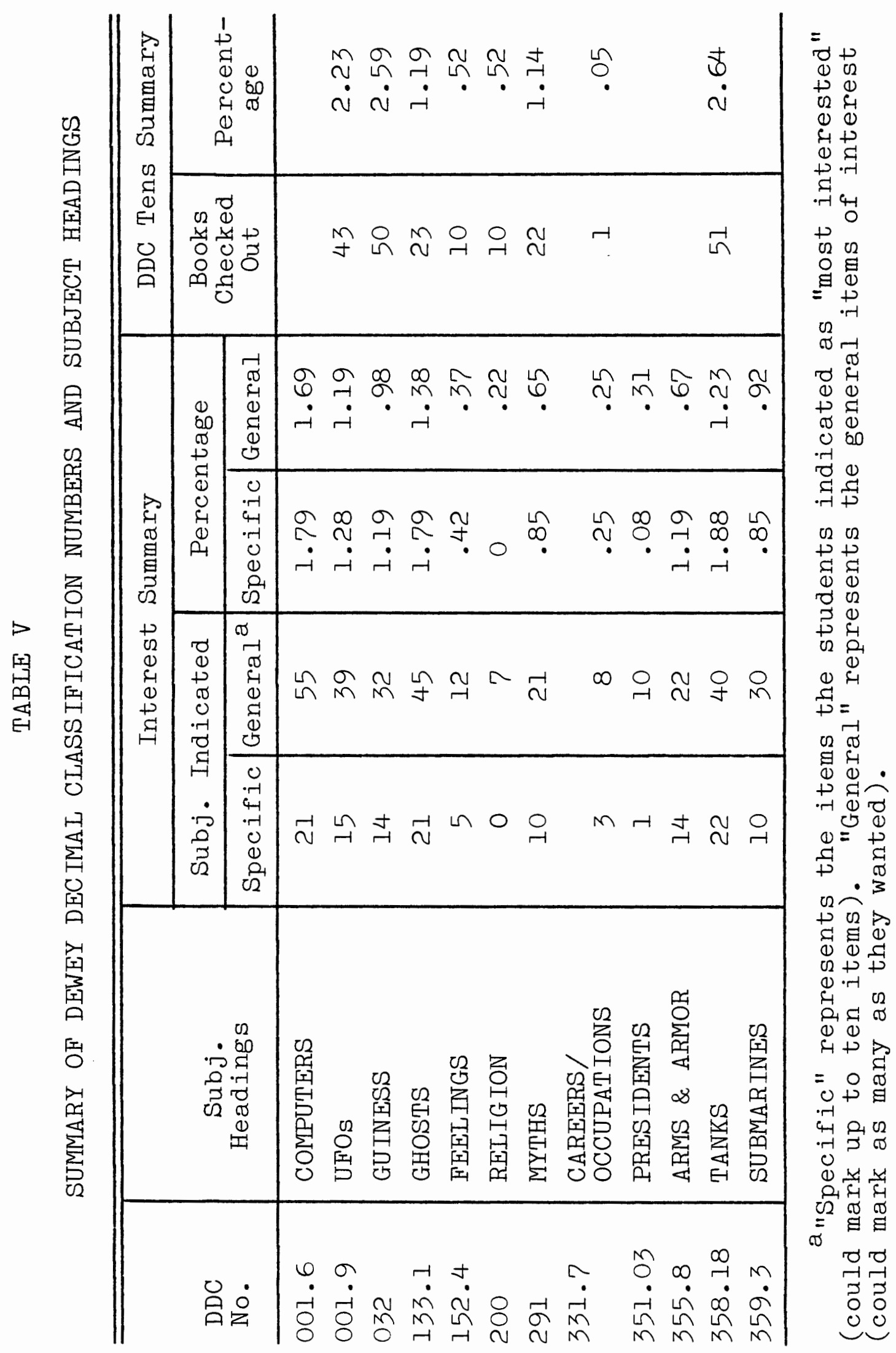




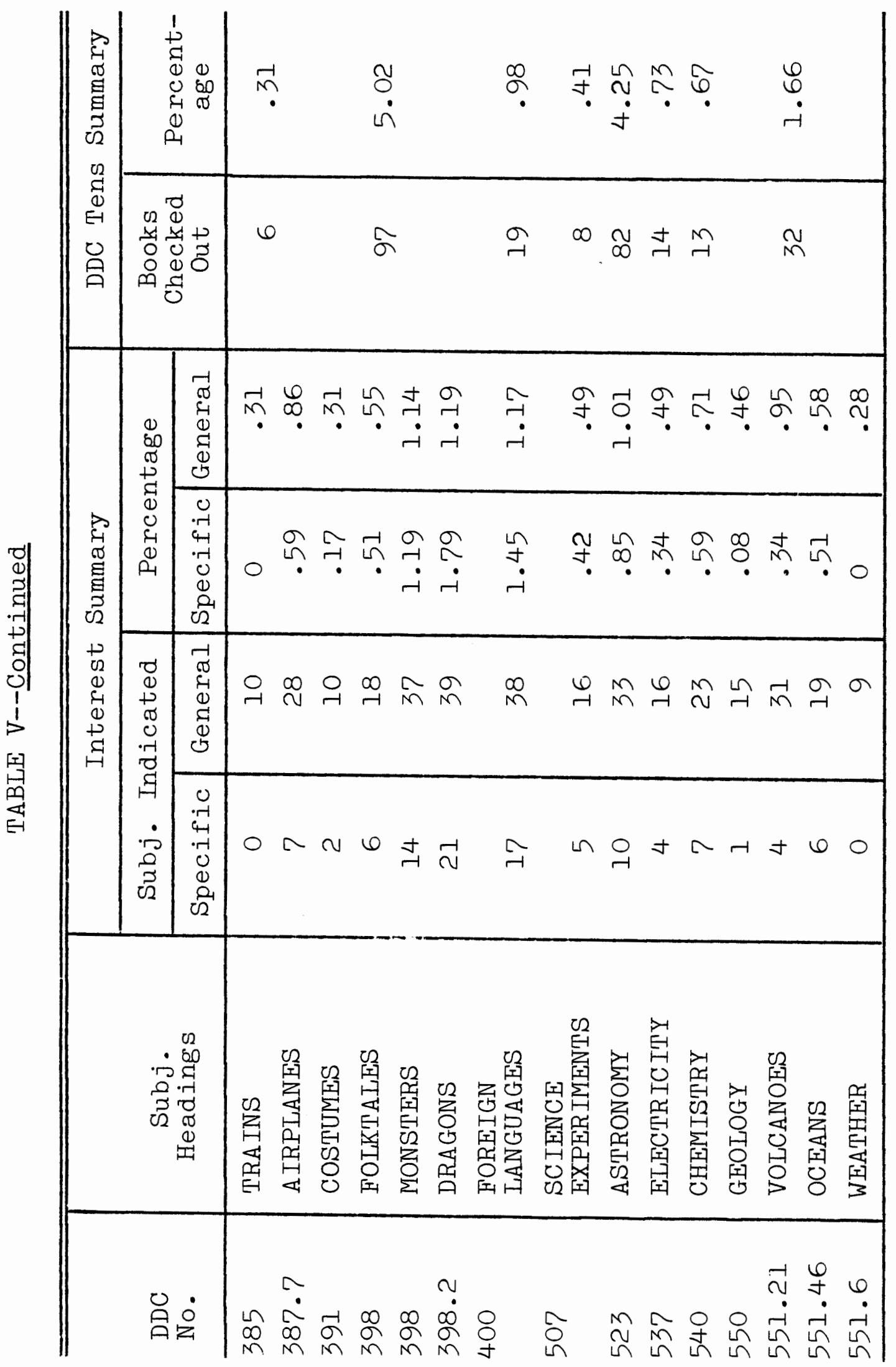




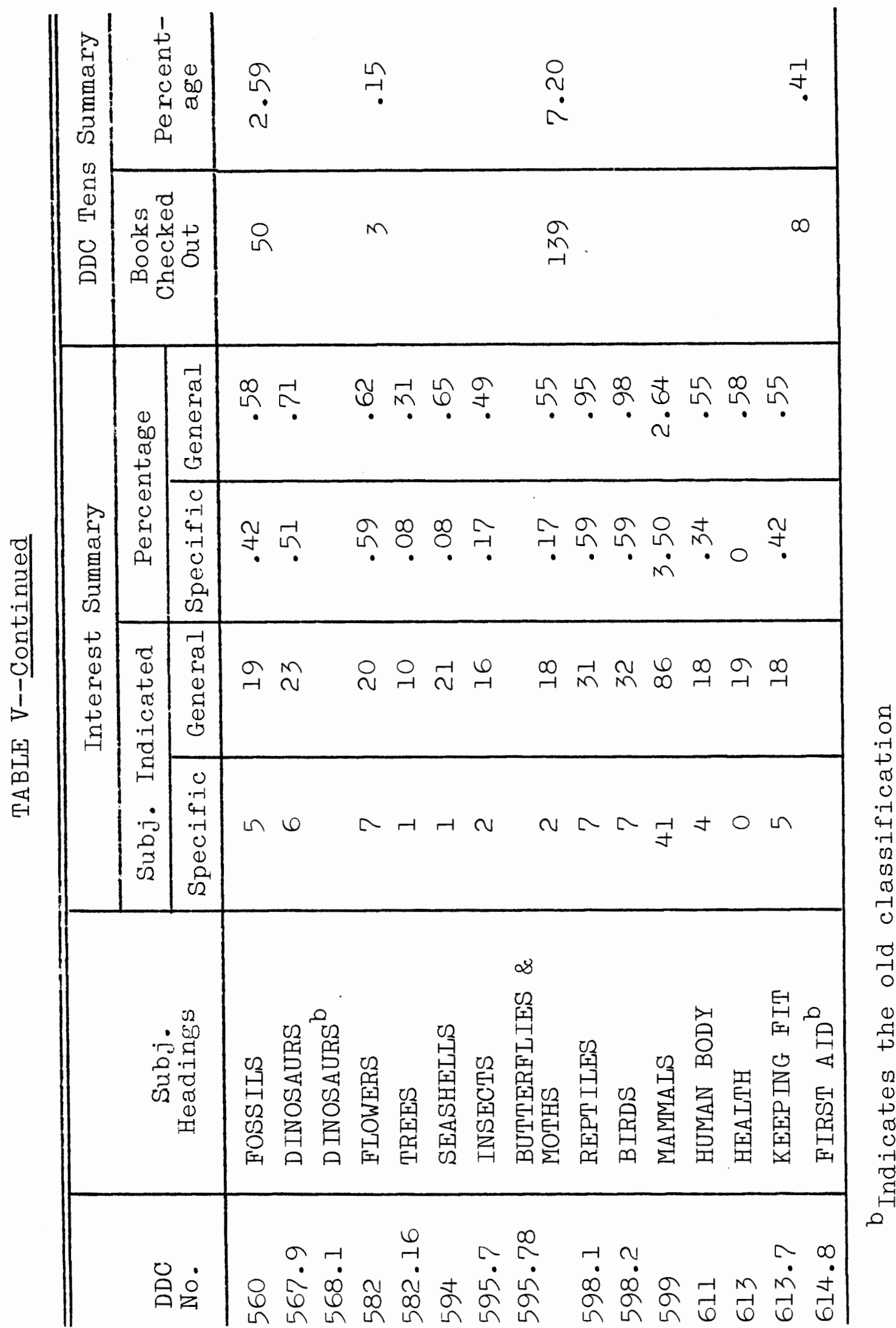




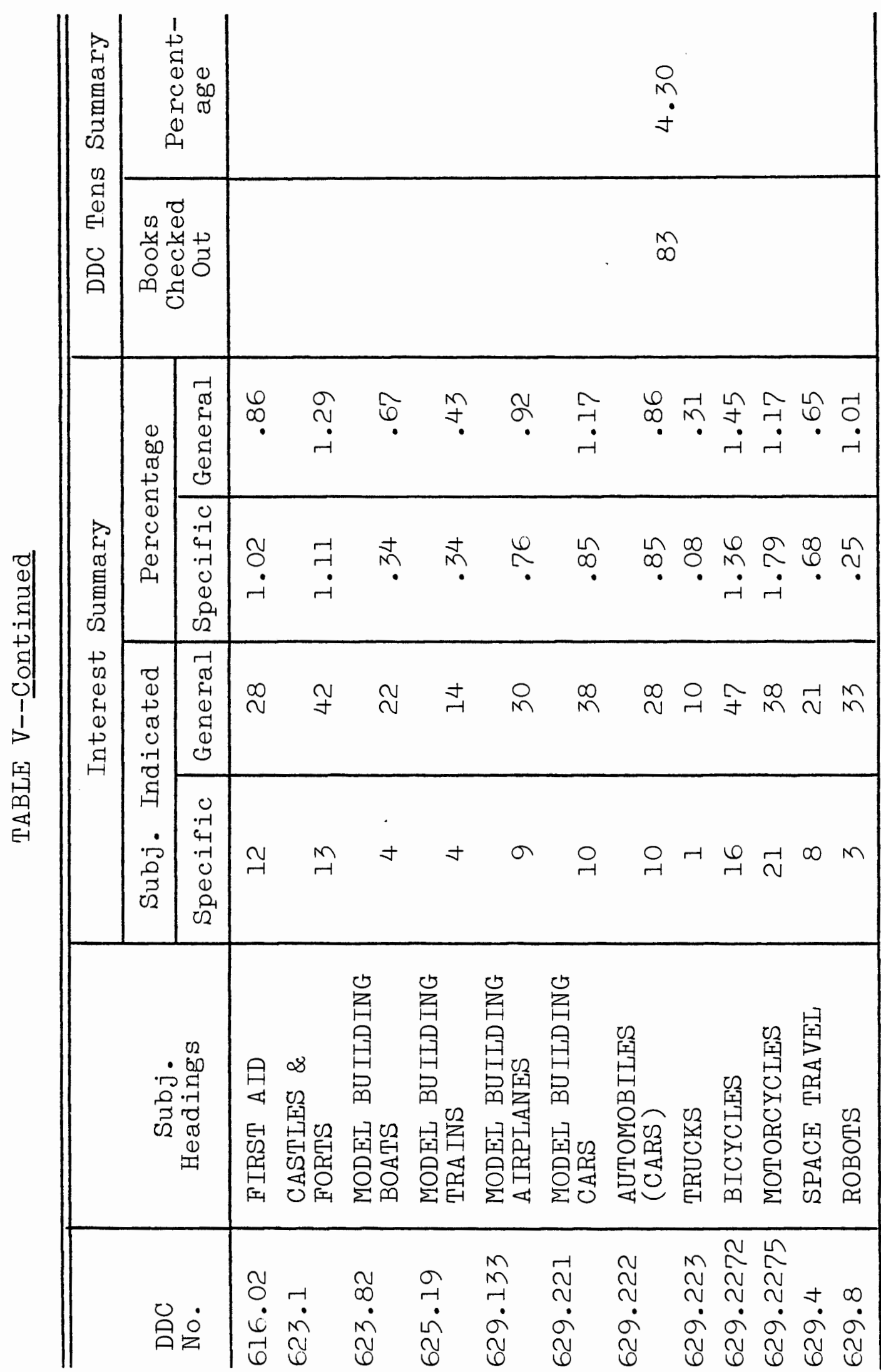




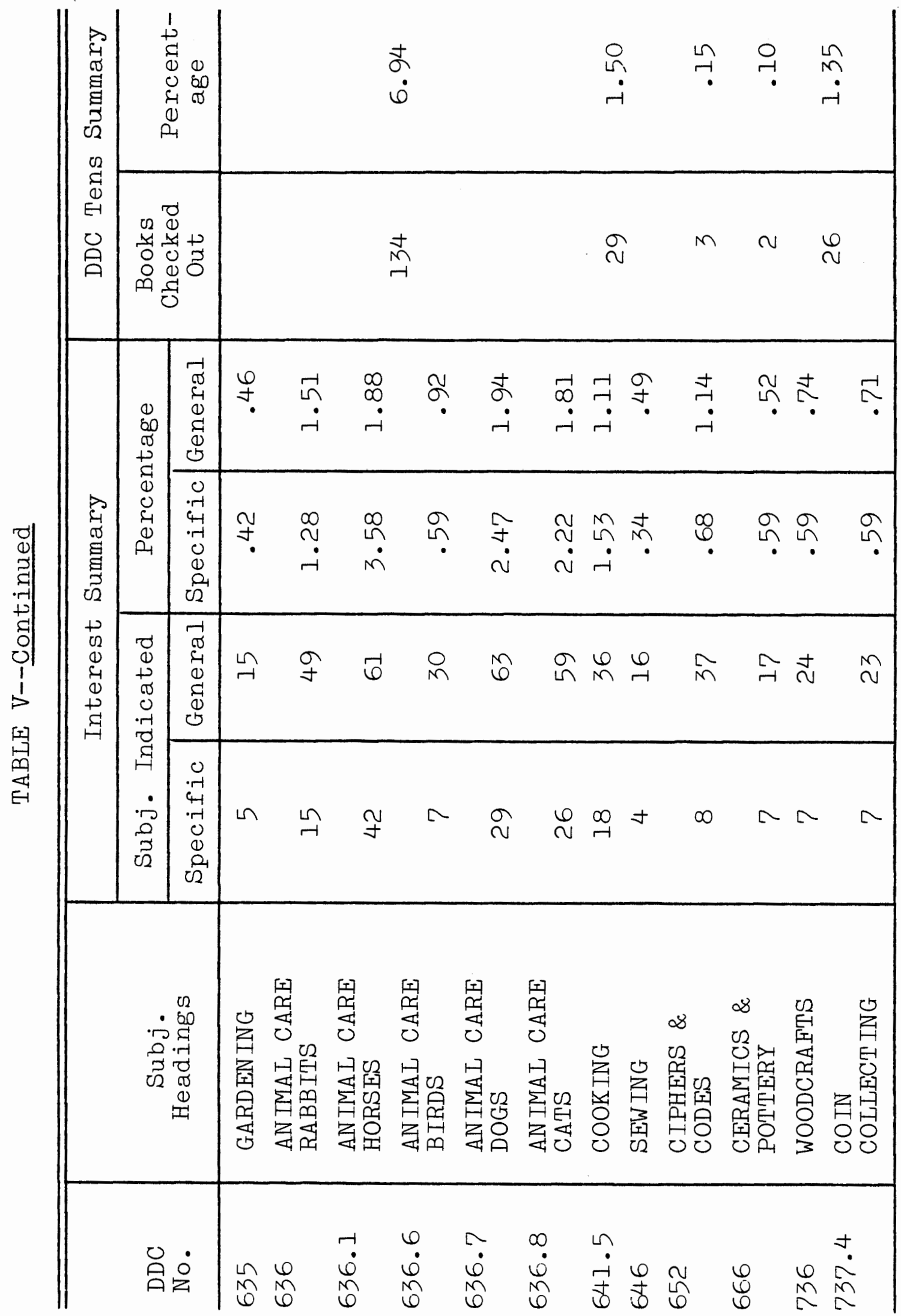




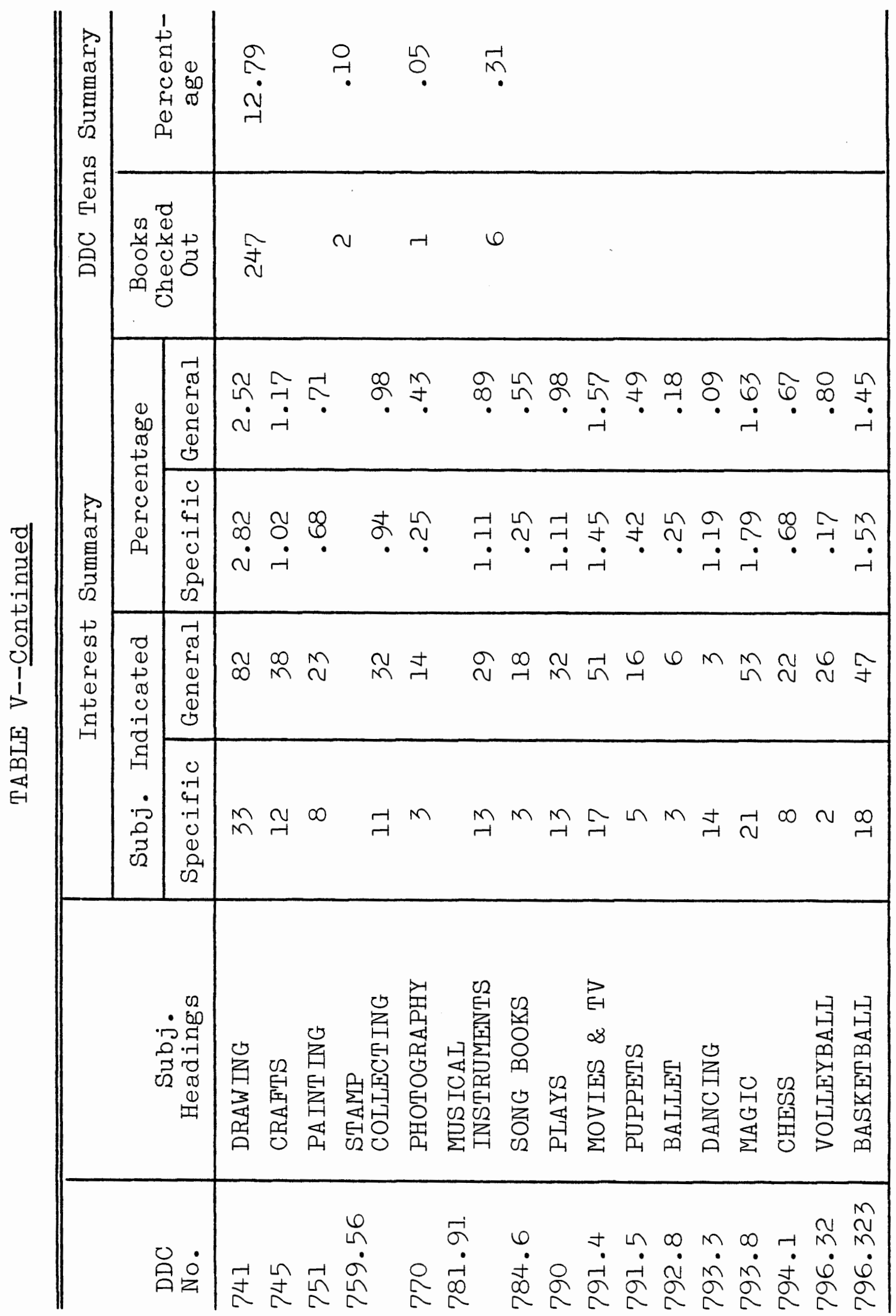




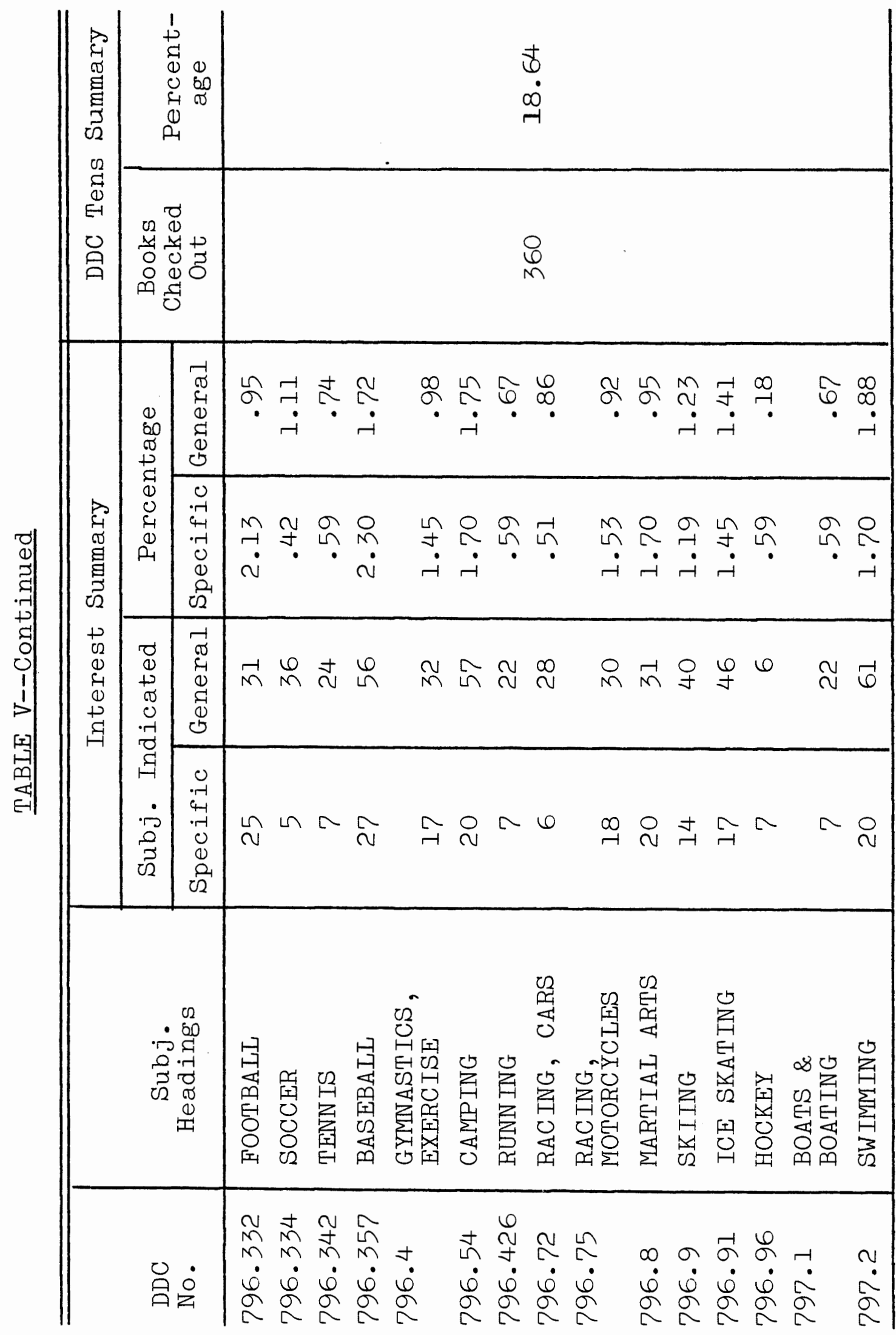




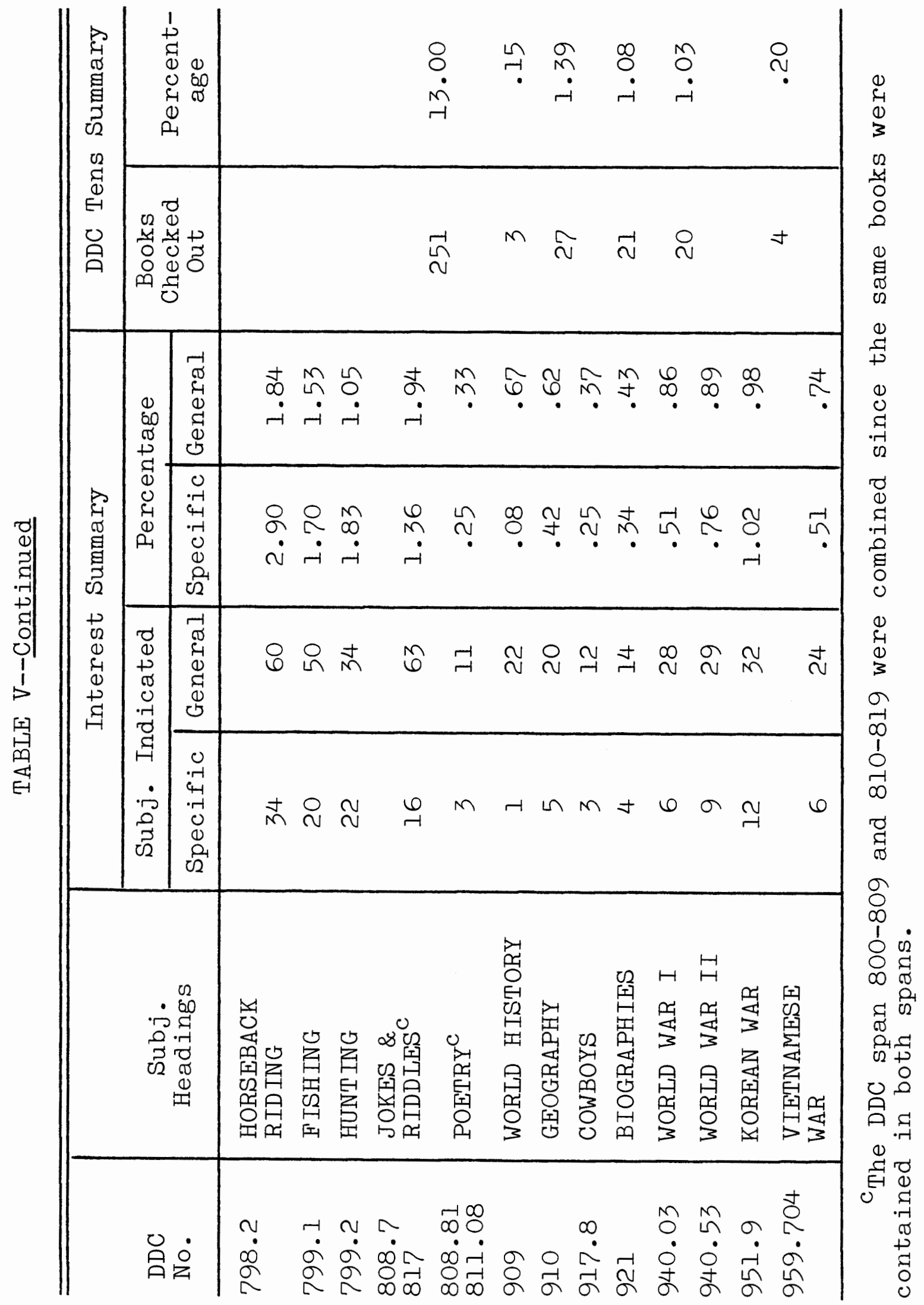




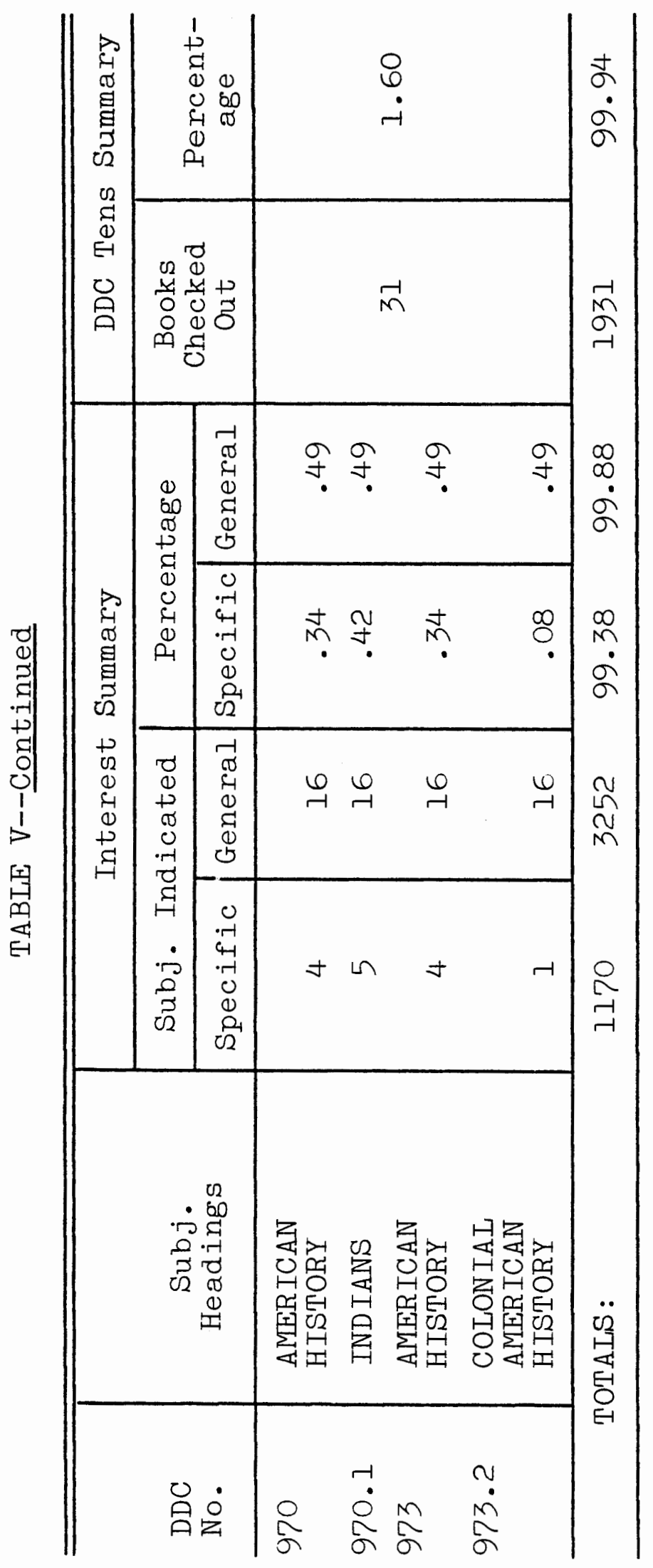




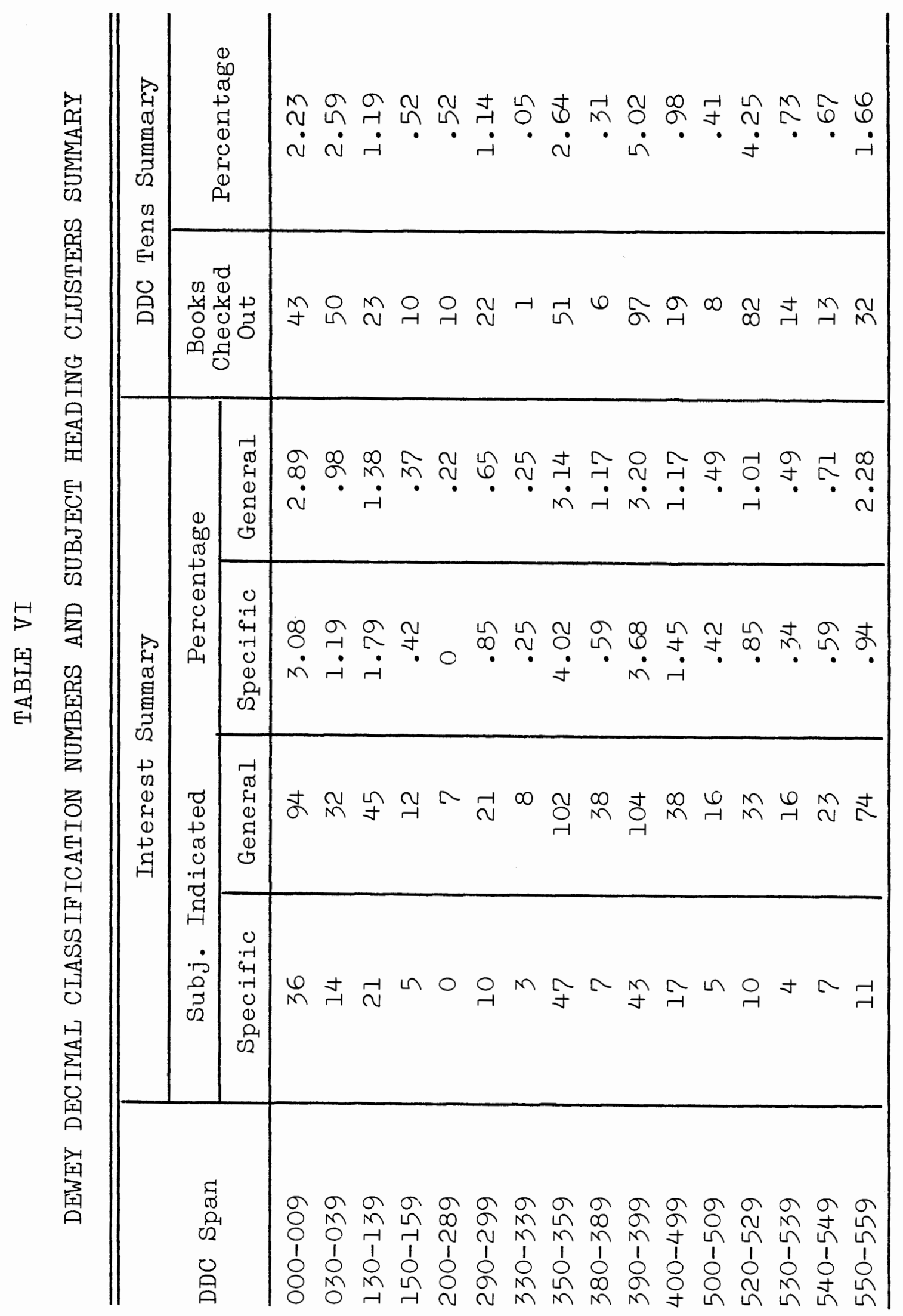




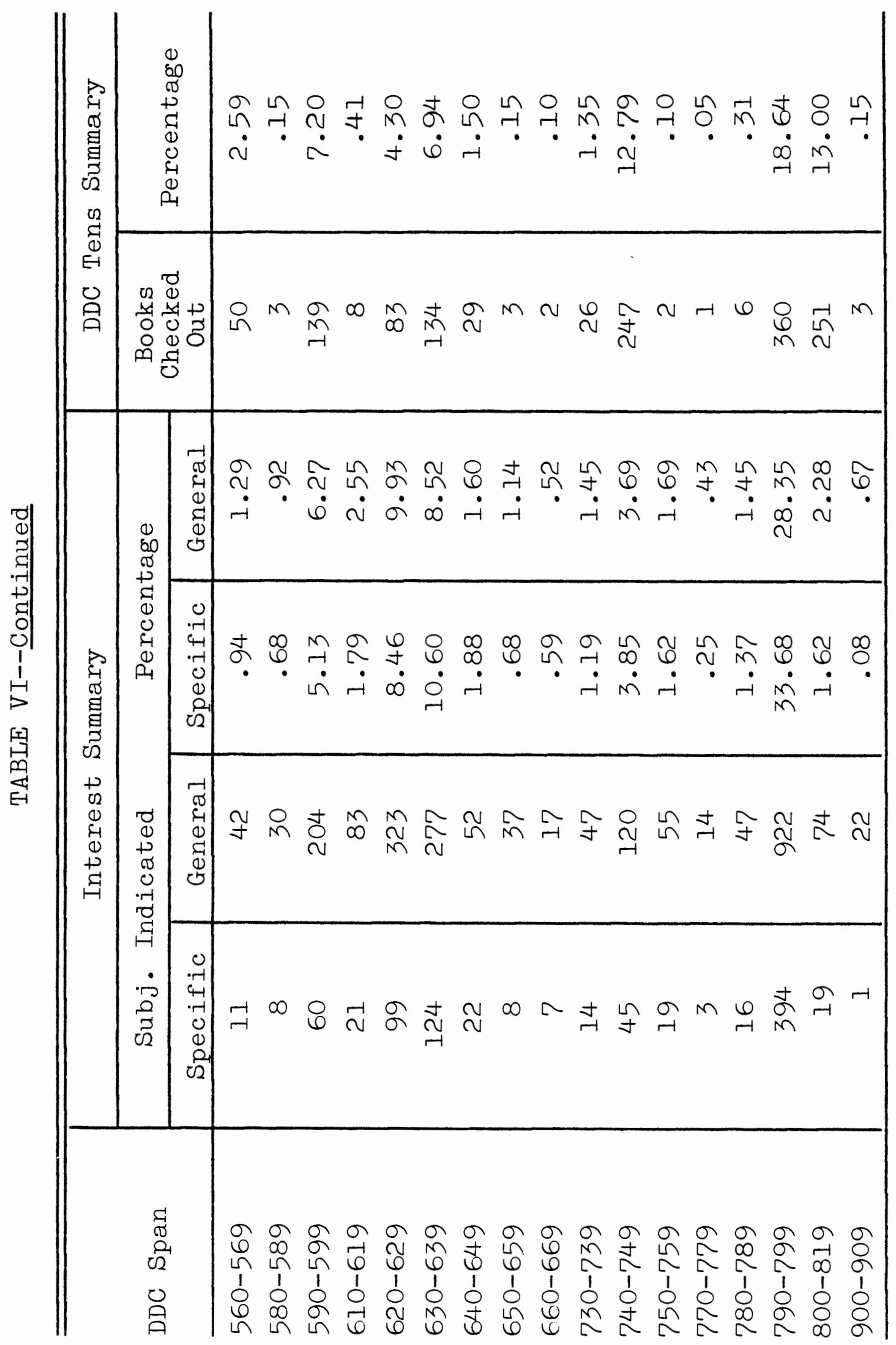




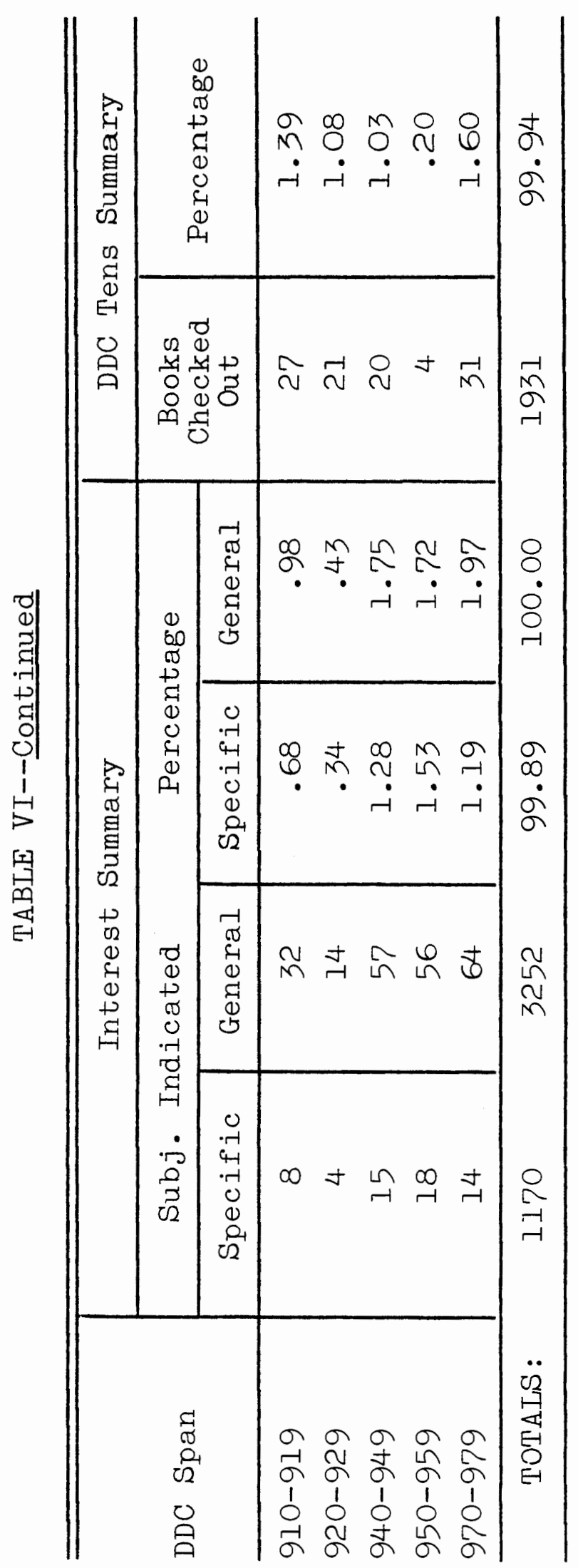


APPENDIX E

RATIO OF BOOKS CHECKED OUT TO MEASURED INTEREST 
RATIO OF BOOKS CHECKED OUT OF THE IIBRARY MEDIA CENTER TO MEASURED INTEREST ARRANGED BY DEWEY DECIMAI

CLASSIFICATION TENS SPAN

\begin{tabular}{|c|c|c|c|c|c|}
\hline \multirow{2}{*}{$\begin{array}{c}\text { Classes by } \\
\text { Groups of } \\
\text { Tens }\end{array}$} & \multirow{2}{*}{$\begin{array}{l}\text { Specific } \\
\text { Interest }\end{array}$} & \multirow{2}{*}{$\begin{array}{l}\text { General } \\
\text { Interest }\end{array}$} & \multirow{2}{*}{$\begin{array}{l}\text { Books } \\
\text { Checked } \\
\text { Out }\end{array}$} & \multicolumn{2}{|c|}{$\begin{array}{c}\text { Ratio of Books } \\
\text { Checked Out to } \\
\text { Interest }\end{array}$} \\
\hline & & & & $\begin{array}{l}\text { Spe- } \\
\text { cific }\end{array}$ & $\begin{array}{l}\text { Gen- } \\
\text { eral }\end{array}$ \\
\hline $000-009$ & 36 & 94 & 43 & 1.2 & .5 \\
\hline $030-039$ & 14 & 32 & 50 & 3.6 & 1.6 \\
\hline Class total & 50 & 126 & 93 & 1.9 & .7 \\
\hline $130-139$ & 21 & 45 & 23 & 1.1 & .5 \\
\hline $150-159$ & 5 & 12 & 10 & 2.0 & .8 \\
\hline Class total & 26 & 57 & 33 & 1.3 & .6 \\
\hline $200-289$ & 0 & 7 & 10 & 0 & 1.4 \\
\hline $290-299$ & 10 & 21 & 22 & 2.2 & 1.0 \\
\hline Class total & 10 & 28 & 32 & 3.2 & 1.1 \\
\hline $330-339$ & 3 & 8 & 1 & .3 & .1 \\
\hline $350-359$ & 47 & 102 & 51 & 1.0 & .5 \\
\hline $380-389$ & 7 & 38 & 6 & .9 & .2 \\
\hline $390-399$ & 43 & 104 & 97 & 2.3 & .9 \\
\hline Class total & 100 & 252 & 155 & 1.6 & .6 \\
\hline $400-499$ & 17 & 38 & 19 & 1.1 & .5 \\
\hline Class total & 17 & 38 & 19 & 1.1 & $\cdot 5$ \\
\hline $500-509$ & 5 & 16 & 8 & 1.6 & .5 \\
\hline $520-529$ & 10 & 33 & 82 & 8.2 & 2.5 \\
\hline $530-539$ & 4 & 16 & 14 & 3.5 & .9 \\
\hline $540-549$ & 7 & 23 & 13 & 1.9 & .6 \\
\hline $550-559$ & 11 & 74 & 32 & 3.0 & .4 \\
\hline $560-569$ & 11 & 42 & 50 & 4.5 & 1.2 \\
\hline $580-589$ & 8 & 30 & 3 & .4 & .1 \\
\hline
\end{tabular}


TABIE VII--Continued

\begin{tabular}{|c|c|c|c|c|c|}
\hline \multirow{2}{*}{$\begin{array}{c}\text { Classes by } \\
\text { Groups of } \\
\text { Tens }\end{array}$} & \multirow{2}{*}{$\begin{array}{l}\text { Specific } \\
\text { Interest }\end{array}$} & \multirow{2}{*}{$\begin{array}{l}\text { General } \\
\text { Interest }\end{array}$} & \multirow{2}{*}{$\begin{array}{l}\text { Books } \\
\text { Checked } \\
\text { Out }\end{array}$} & \multicolumn{2}{|c|}{$\begin{array}{l}\text { Ratio of Books } \\
\text { Checked Out to } \\
\text { Interest }\end{array}$} \\
\hline & & & & $\begin{array}{r}\text { Spe- } \\
\text { cific }\end{array}$ & $\begin{array}{l}\text { Gen- } \\
\text { eral }\end{array}$ \\
\hline $590-599$ & 60 & 204 & 139 & 2.3 & .7 \\
\hline Class total & 116 & 438 & 341 & 3.0 & .8 \\
\hline $610-619$ & 21 & 83 & 8 & .4 & .1 \\
\hline $620-629$ & 99 & 323 & 83 & .8 & .3 \\
\hline $630-639$ & 124 & 277 & 134 & 1.1 & .5 \\
\hline $640-649$ & 22 & 52 & 29 & 1.3 & .6 \\
\hline $650-659$ & 8 & 37 & 3 & .4 & .1 \\
\hline $660-669$ & 7 & 17 & 2 & .3 & .1 \\
\hline Class total & 281 & 789 & 259 & .9 & .3 \\
\hline $730-739$ & 14 & 47 & 26 & 1.9 & .6 \\
\hline $740-749$ & 45 & 120 & 247 & 5.5 & 2.1 \\
\hline $750-759$ & 19 & 55 & 2 & .1 & .04 \\
\hline $770-779$ & 3 & 14 & 1 & .3 & .07 \\
\hline $780-789$ & 16 & 47 & 6 & .4 & .1 \\
\hline $790-799$ & 394 & 922 & 360 & .9 & .4 \\
\hline Class total & 491 & 1205 & 642 & 1.3 & .5 \\
\hline $800-819$ & 19 & 74 & 251 & 13.2 & 3.4 \\
\hline Class total & 19 & 74 & 251 & 13.2 & 3.4 \\
\hline $900-909$ & 1 & 22 & 3 & 3.0 & .1 \\
\hline $910-919$ & 8 & 32 & 27 & 3.4 & .8 \\
\hline $920-929$ & 4 & 14 & 21 & 5.2 & 1.5 \\
\hline $940-949$ & 15 & 57 & 20 & 1.3 & .4 \\
\hline $950-959$ & 18 & 56 & 4 & .2 & .07 \\
\hline $970-979$ & 14 & 64 & 31 & 2.2 & .5 \\
\hline Class total & 60 & 245 & 106 & 1.8 & .4 \\
\hline TOTALS : & 1170 & 3252 & 1931 & 1.7 & .6 \\
\hline
\end{tabular}


APPENDIX F

STUDENT INTEREST INVENTORY SPECIFIC AND GENERAI DESIRES AND BOOKS CHECKED OUT 


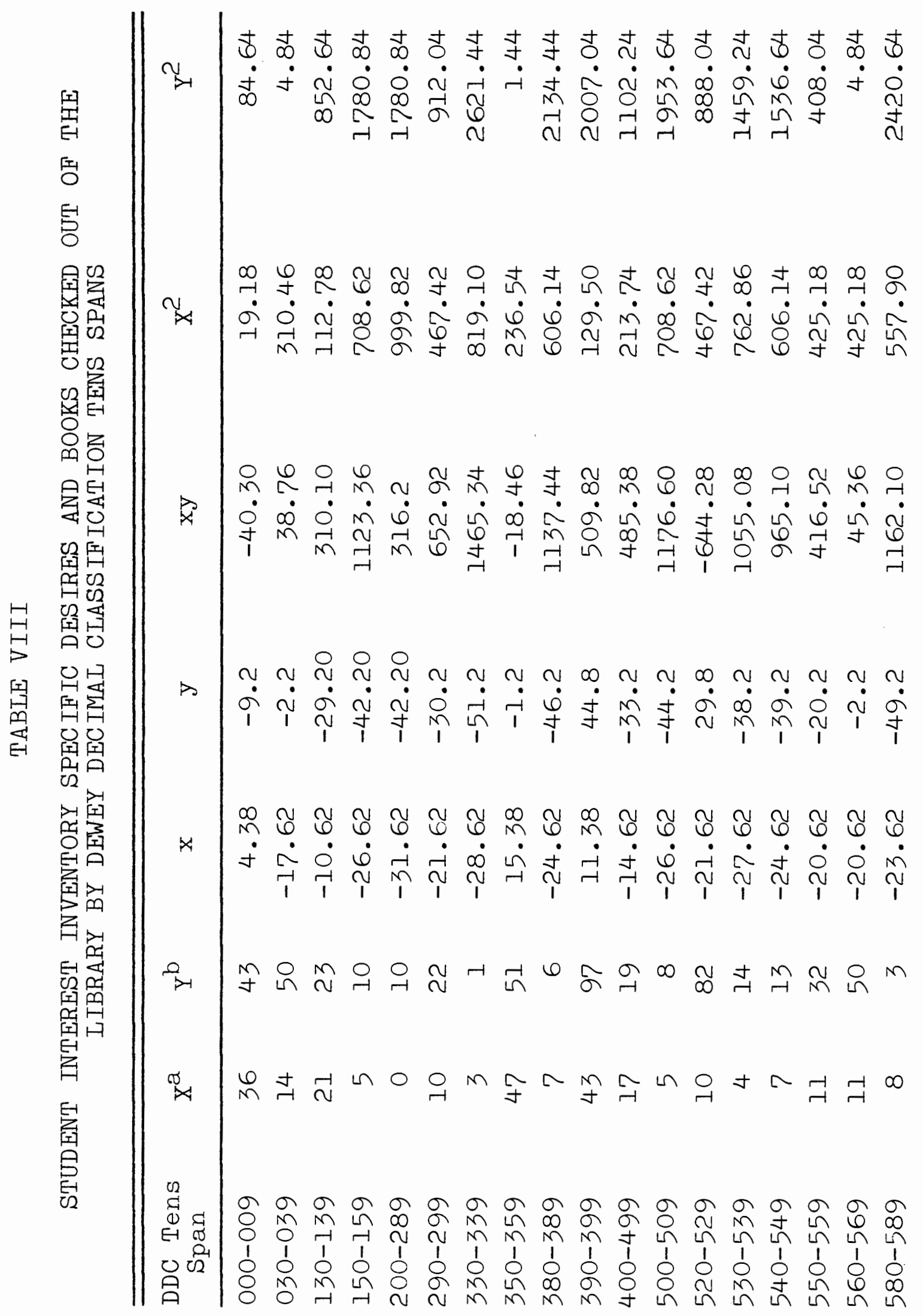




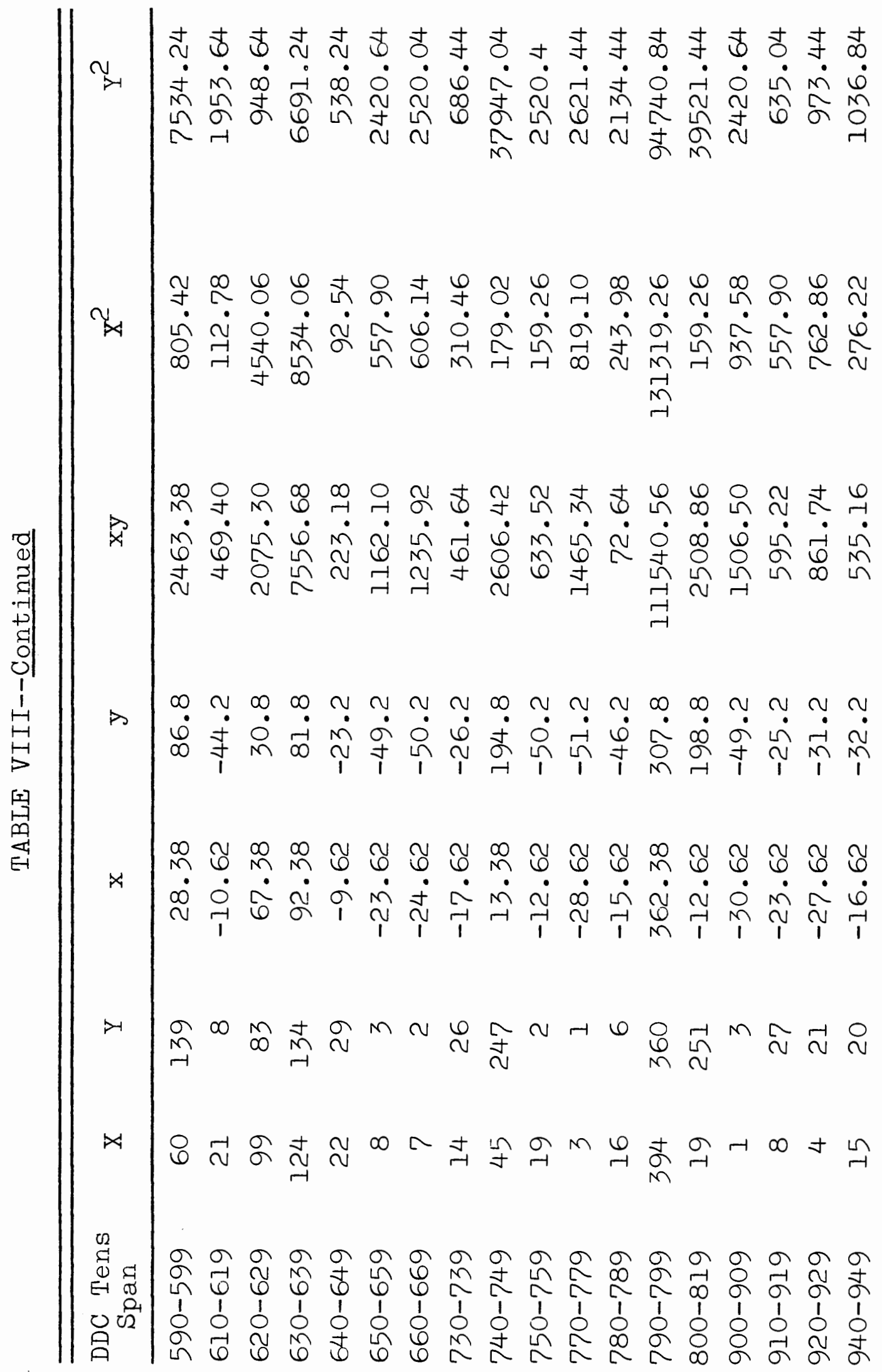




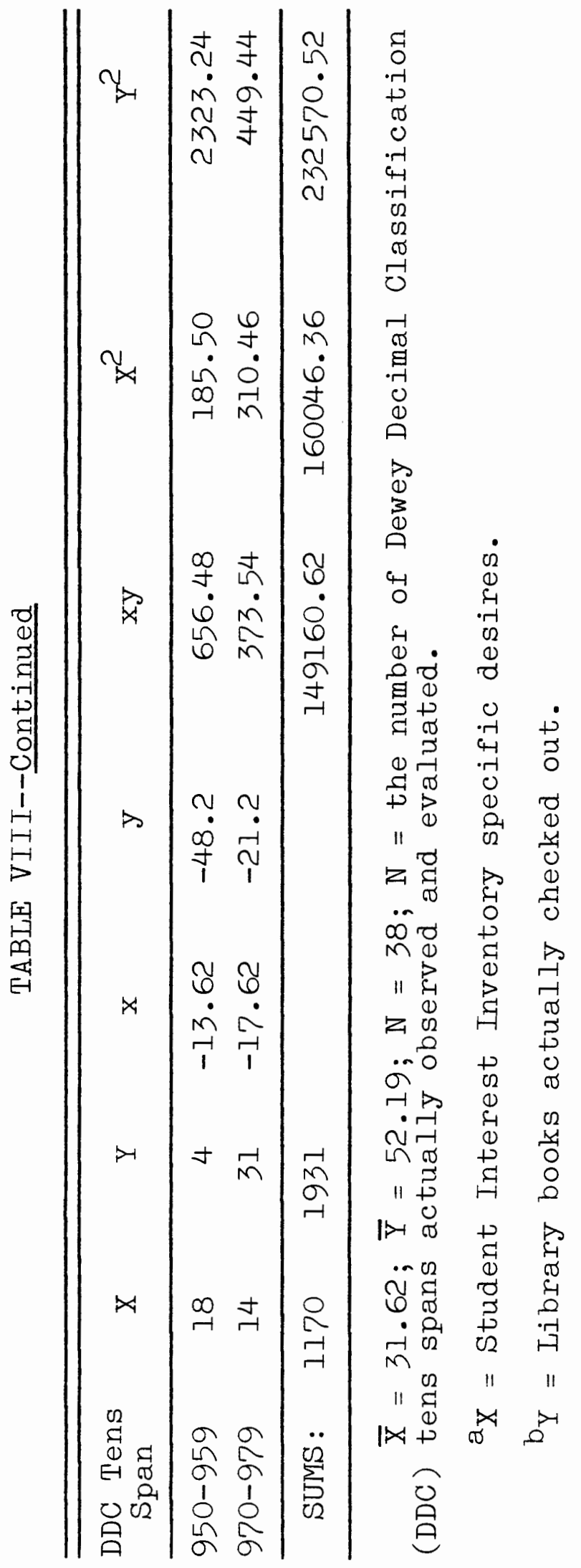




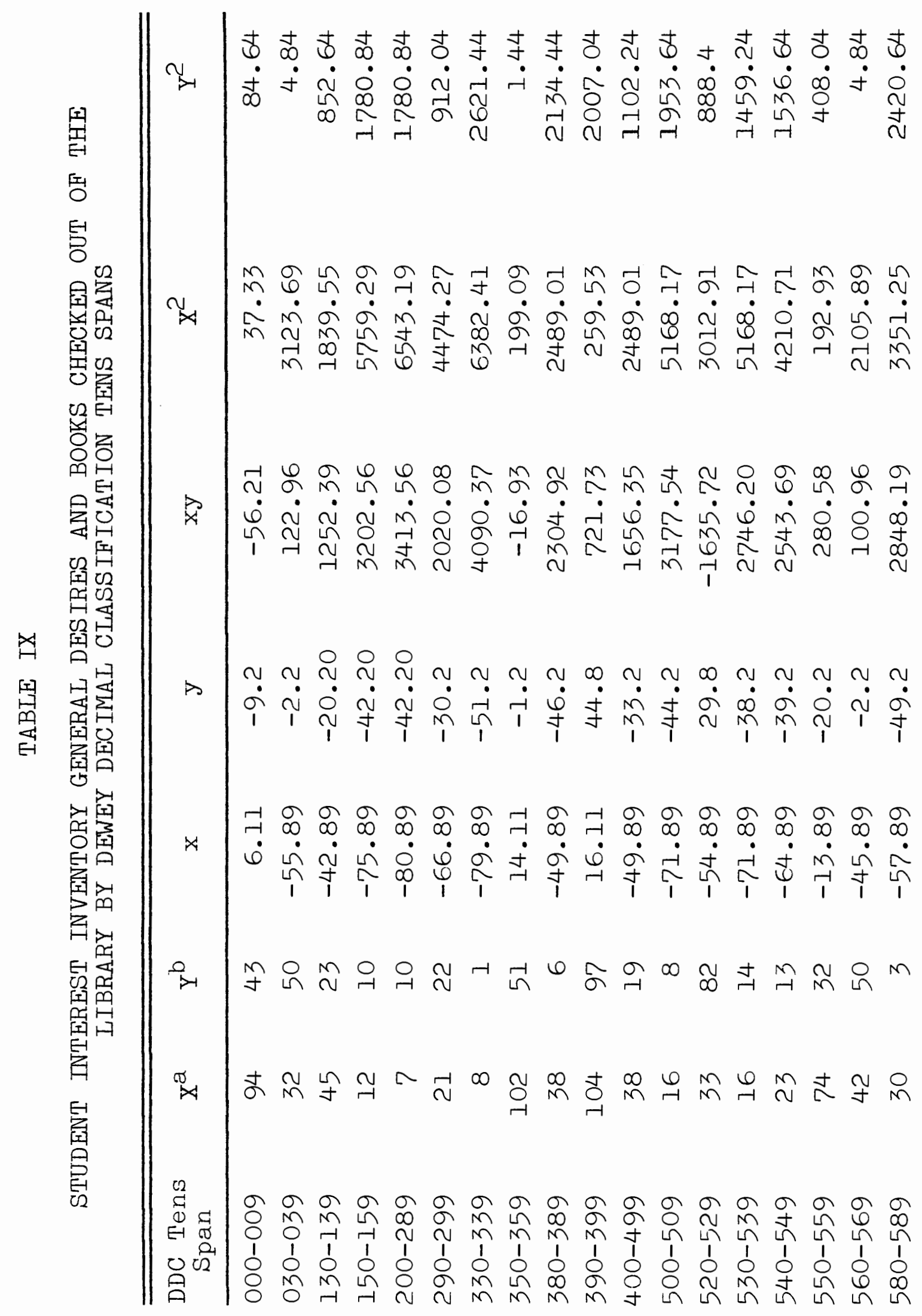




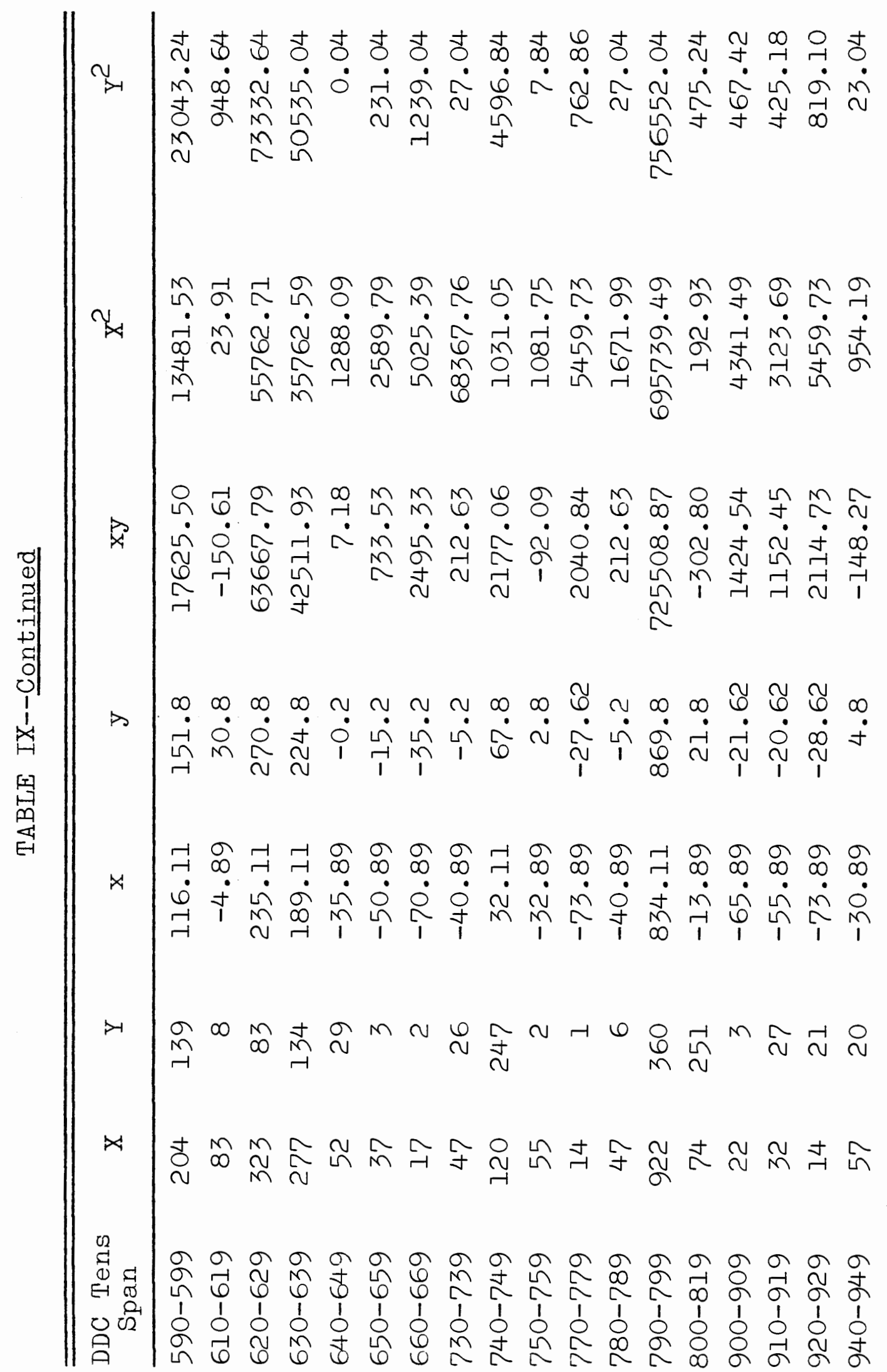




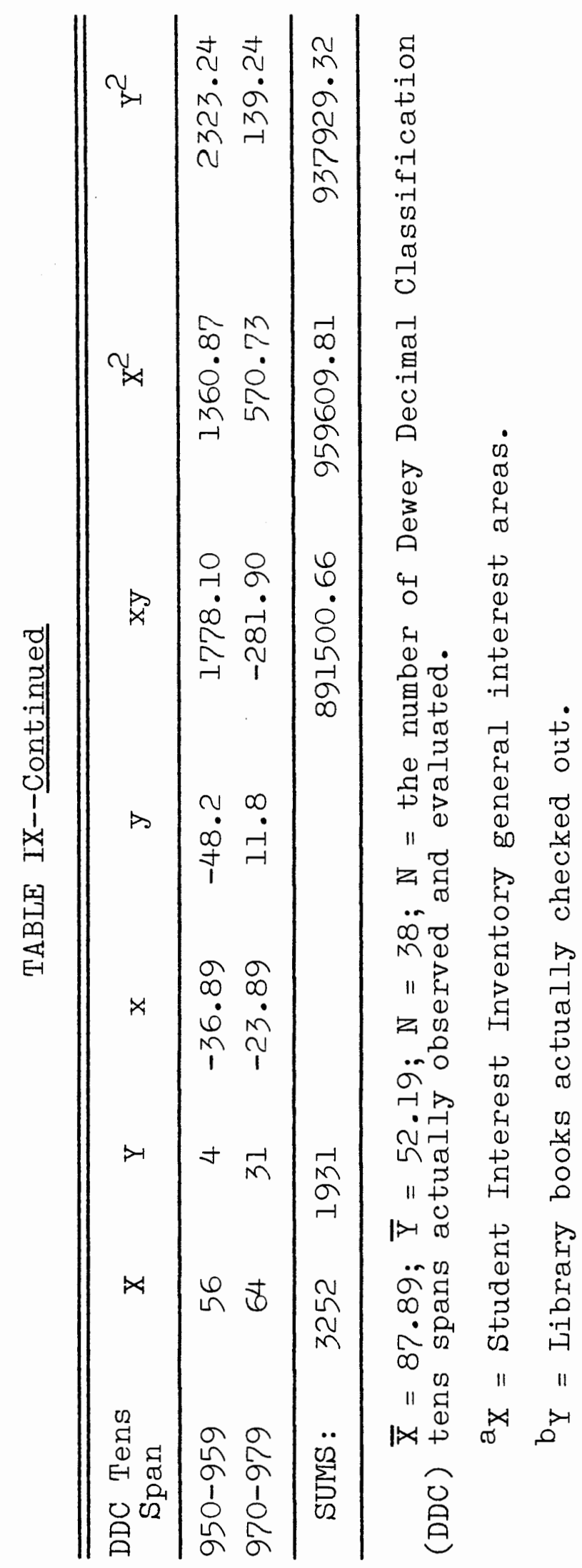

